\title{
Lansoprazole-induced osteoporosis via the IP3R- and SOCE-mediated calcium signaling pathways
}

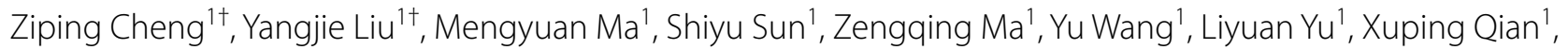
Luning Sun ${ }^{1}$, Xuehui Zhang ${ }^{2}$, Yun Liu ${ }^{4^{*}}$ and Yongqing Wang ${ }^{1,2,3^{*}}$ (D)

\begin{abstract}
Background: Many clinical studies have shown a correlation between proton pump inhibitors (PPIs) and osteoporosis or fractures. The purpose of this study was to establish a murine model of chronic oral PPI administration to verify whether PPIs caused bone metabolic impairment and investigate the relevant molecular mechanism underlying the effects of PPIs on MC3T3-E1 murine osteoblasts.

Methods: A lansoprazole-induced bone loss model was used to investigate the damaging effects of PPIs. In vivo, immunohistochemistry, Hematoxylin-Eosin (HE) staining, micro-CT analysis, and blood biochemical analyses were used to evaluate the effect of lansoprazole on bone injury in mice. In vitro, the effects of lansoprazole and related signaling pathways in MC3T3-E1 cells were investigated by CCK-8 assays, EdU assays, flow cytometry, laser confocal microscopy, patch clamping, reverse transcription-quantitative polymerase chain reaction and Western blotting.
\end{abstract}

Results: After 6 months of lansoprazole gavage in ICR mice, the micro-CT results showed that compared with that in the vehicle group, the bone mineral density (BMD) in the high-dose group was significantly decreased $(P<0.05)$, and the bone microarchitecture gradually degraded. Biochemical analysis of bone serum showed that blood calcium and phosphorus were both decreased $(P<0.01)$. We found that long-term administration of lansoprazole impaired skeletal function in mice. In vitro, we found that lansoprazole (LPZ) could cause calcium overload in MC3T3-E1 cells leading to apoptosis, and 2-APB, an inhibitor of IP3R calcium release channel and SOCE pathway, effectively blocked increase in calcium caused by LPZ, thus protecting cell viability.

Conclusions: Longterm administration of LPZ induced osteoporotic symptoms in mice, and LPZ triggered calcium increases in osteoblasts in a concentration-dependent manner. Intracellular calcium ([Ca $\left.\left.{ }^{2+}\right]_{i}\right)$ persisted at a high concentration, thereby causing endoplasmic reticulum stress (ERS) and inducing osteoblast apoptosis.

Keywords: Lansoprazole, IP3R, SOCE, ER stress, Calcium overload, Osteoporosis

\footnotetext{
*Correspondence: liuyun@njmu.edu.cn; wyqjsph@163.com

${ }^{\dagger}$ Ziping Cheng and Yangjie Liu contributed equally to this work

${ }^{1}$ Research Division of Clinical Pharmacology, The First Affiliated Hospital of Nanjing Medical University and Jiangsu Province Hospital, 300 Guangzhou Road, Nanjing 210009, China

${ }^{4}$ Department of Geriatrics Endocrinology, The First Affiliated Hospital of Nanjing Medical University, Jiangsu Province Hospital, 300 Guangzhou Road, Nanjing 210029, China

Full list of author information is available at the end of the article
}

\section{Introduction}

PPIs have long been used as the first-line drugs to treat gastric acid-related diseases by irreversibly binding to $\mathrm{H}^{+} / \mathrm{K}^{+}$-ATPase to inhibit gastric acid secretion (Chen et al. 2016). Generally, PPIs are considered to be well tolerated in clinical practice. However, more than $40 \%$ of clinical cases involve irrational drug use, and some patients continue to use PPIs for a long time regardless 
of the clinical indicators (Grant et al. 2006). To date, the majority of PPIs include omeprazole, lansoprazole, pantoprazole, rabeprazole, esomeprazole and ilaprazole (Ito and Jensen 2010; Gyawali, 2017). In 2010, the FDA warned that patients taking PPIs for more than a year or those taking higher doses may have increased risk of hip, wrist, and spine fractures. Clinical meta-analyses have also shown that PPI use increases the risk of hip, spine, or vertebral fracture (Ito and Jensen 2010; Yu et al. 2011; van der Hoorn et al. 2015; Chen et al. 2016; Poly et al. 2018), and patients treated with PPIs for two years are more likely to have a hip fracture $(\mathrm{OR}=1.30$, $\mathrm{CI}=1.21-1.39)$ (Corley et al. 2010). In addition, animal experiments showed that pantoprazole treatment for 12 weeks had a negative effect on bone metabolism in young male rats (Matuszewska et al. 2016), and pantoprazole $(100 \mathrm{mg} / \mathrm{kg} /$ day) could affect fracture healing in mice (Histing et al. 2012; Menger et al. 2020). However, there have been few studies on the molecular mechanism of the effect of PPIs on osteocytes in vitro.

Bone homeostasis is maintained by a balance between osteoclast (OC)-mediated bone resorption and osteoblast (OB)-mediated bone formation mediated (Yin et al. 2019). To date, the literature associated with PPIs and bone loss has focused mainly on the relationship between PPIs and OCs, and few studies have focused on PPIs and OBs (Yuan et al. 2010; Jo 2015). Since new bone formation depends largely on osteoblasts, any factors that promote osteoblast apoptosis could increase the risk of osteoporosis (Guo et al. 2014; Elias and Targownik 2019). In this study, we focused on the of role of OBs in skeletal system injury induced by PPIs.

Naseri et al.showed that both omeprazole and lansoprazole could induce arterial relaxation in a timedependent manner, and this effect was associated the regulation of intracellular calcium (Naseri and Yenisehirli 2006). Schillinger showed that pantoprazole could affect the uptake of $\mathrm{Ca}^{2+}$ in the sarcoplasmic reticulum (SR) by inhibiting SERCA, thus reducing the transient amplitude of calcium and myocardial contractility (Schillinger et al. 2007; Sato et al. 2017). Yurtsever and Aydin hypothesized that omeprazole and lansoprazole may inhibit Rho-kinase, thus affecting $\mathrm{Ca}^{2+}$ regulation or blocking calcium channels to inhibit muscle contraction (Aydin et al. 2003; Yurtsever et al. 2011). Aydan (Yenisehirli and Onur 2006) used lansoprazole $(100-300 \mu \mathrm{M})$ to inhibit $\mathrm{Ca}^{2+}$ entry through voltagegated channels. Thus, it seems that PPIs may have an effect on intracellular calcium homeostasis. In addition, $\mathrm{Ca}^{2+}$-ATPase (PMCA), SERCA, $\mathrm{Na}^{+} / \mathrm{K}^{+}$-ATPase, and gastric $\mathrm{H}^{+} / \mathrm{K}^{+}$-ATPase are all P-type ATPases and share high homology with each other (Toyoshima and Cornelius 2013). Furthermore, intracellular calcium overload could significantly induce endoplasmic reticulum stress (Mohsin et al. 2020).

Previous studies have shown that oxidative stress can modulate multiple signaling pathways by activating or inhibiting multiple cytokine and enzyme activities (Zhang et al. 2013). These factors could affect the expression of genes, accelerate apoptosis in cells involved in osteogenesis, including bone mesenchymal stem cells (BMSCs), osteoblasts and osteocytes, and increase the proliferation and differentiation of osteoclasts. This apoptosis results in a decrease in bone resorption relative to bone formation and changes the dynamic balance between osteoclast absorption of bone tissue and osteoblast formation of bone tissue, leading to osteoporosis (Liao et al. 2016; Nie et al. 2019).

ALP, OCN, Runx2, and CoLI $\alpha$ are genes that promote osteoblast differentiation, while Grp78, Caspase-12, Bcl-2, Bax, ATF4, and CHOP are significantly associated with endoplasmic reticulum oxidative stress (Huang et al. 2018; Li et al. 2019; Nagaoka et al. 2019). Thus, we hypothesized that LPZ could inhibit SERCA in OBs, leading to calcium homeostasis disorder. The purpose of this study was to investigate the effect of $\mathrm{LPZ}$ on $\left[\mathrm{Ca}^{2+}\right]_{\mathrm{i}}$ changes and the viability of MC3T3-E1 cells in vitro and whether LPZ could promote endoplasmic reticulum oxidative stress and induce osteoblast apoptosis. Furthermore, whether LPZ caused OP in mice was examined. The combination of in vitro and in vivo experiments provided a potential mechanism for the deleterious effects of PPIs on the skeletal system.

\section{Materials and methods \\ Animals}

ICR mice (SPF grade, 18-22 g, aged 6-8 weeks, half male and half female) were provided by Nanjing Jiangning District Qinglongshan Animal Farm Quality certificate of experimental animals: no. 201824637; production license NO. SCXK (SU) 2017-0-001).

\section{Drugs}

Lansoprazole (purity 99.45\%) was provided by Wuhan Yuancheng Co-founder Technology Co., Ltd. Sodium carboxymethyl cellulose (CMC-Na), (viscosity: 6003000 mPa.s, USP grade) was obtained from Shanghai Macklin Biochemical Co., Ltd.

\section{Drug administration}

The mice were administered lansoprazole orally for 6 months. All mice were placed in separate cages and fed standard laboratory rodent chow and water under standard conditions. During the experiments, the mice were maintained at a constant temperature of $26{ }^{\circ} \mathrm{C}$ with a 12-h light-dark cycle. After 3 days of adaptive feeding, 
the mice were randomly divided into three groups: the lansoprazole high-dose group $(1000 \mathrm{mg} / \mathrm{kg})$, the lansoprazole low-dose group $(250 \mathrm{mg} / \mathrm{kg})$, and the control group $(0.5 \% \mathrm{CMC}-\mathrm{Na})$. The dose was calculated as follows: (unit: $\mathrm{ml}$ ) $=0.02 \times \mathrm{m}$ (unit: $\mathrm{g}$ ). After the mice were fed for 6 months, the mice in each group were randomly selected to determine the bone mineral density and serum biochemical indices.

\section{Microcomputed tomography (micro-CT)}

Ten mice were randomly selected from each group and sent to the Animal Experimental Center of Nanjing Medical University. After being anesthetized, the mice were subjected to SkyScan1176 in vivo micro-CT scans of the right femur. Using a $12.59 \mu \mathrm{M}$ pixel size, we used an X-ray at $50 \mathrm{kV}$ and $455 \mu \mathrm{A}$ to scan the distal metaphysis of the femur. Regions of interest (ROIs) of cancellous bone were taken from layer 50 to layer 100 distant from the growth plate.

\section{Mouse femur biomechanical examination}

Six mice were randomly selected from each group and sacrificed, the complete right femur was collected, and the maximum bone load (maximum breaking force) and the bone structural strength (maximum crushing force) of the femur samples were measured by a YLS-16A small animal bone strength instrument. The apparatus maximum applied pressure was $25 \mathrm{~kg}$, the test bone length range was $20-75 \mathrm{~mm}$, and the minimum reading was $0.001 \mathrm{~kg}$.

\section{Mouse serum biochemical indicator analysis}

After the final administration, peripheral whole blood samples were collected in $1.5 \mathrm{ml}$ plastic centrifuge tubes. Blood samples were centrifuged at $3000 \mathrm{rpm}$ for $10 \mathrm{~min}$, the supernatant was collected, and serum inorganic phosphorus (S-IP), serum calcium (S-Ca) and serum alkaline phosphatase (S-ALP) were measured by an automatic biochemical analyzer.

\section{Cell culture}

MC3T3-E1 cells were cultured in $\alpha$-MEM medium (Gibco, 11095080) supplemented with 10\% fetal bovine serum (FBS) (Biological, 4-001-1ACS), $100 \mathrm{mg} / \mathrm{dl}$ glucose, and $1 \%$ antibiotics $(100 \mathrm{U} / \mathrm{ml}$ penicillin $\mathrm{G}$ and $100 \mathrm{mg} / \mathrm{ml}$ streptomycin) (Gibco, $15140-122)$ at $37{ }^{\circ} \mathrm{C}$ in a humidified atmosphere of $5 \% \mathrm{CO}_{2}$. The cells were used for future experiments $70-80 \%$ confluency.

\section{Cell viability assay}

We chose a dose range of $1-50 \mu \mathrm{M}$ because in extracellular fluid, the effective concentration of PPIs was relatively low $(1-50 \mu \mathrm{M})$, which was almost equivalent to the clinical blood concentration of $20-40 \mathrm{mg} / \mathrm{dl}$ (Olbe et al. 2003). Pharmacokinetic analysis of clinical proton pump inhibitors showed that the maximum blood concentration of lansoprazole was in the range of 1-15 $\mu \mathrm{M}$. CCK-8 (Beyotime, C0038) and EdU kits (Beyotime, C0078S) were used to study the effects of PPIs on the proliferation of MC3T3-E1 cells. MC3T3-E1 cells were seeded in 96-well plates (density: 8000 cells/well) until the cells reached $\sim 70-80 \%$ confluence, after which the cells were treated with LPZ. MC3T3-E1 cells were incubated for $24 \mathrm{~h}$ in $\alpha$-MEM $/ 10 \%$ FBS containing different concentrations of $\operatorname{LPZ}(0,5,10,20,50 \mu \mathrm{M})$, and cells in the vehicle group were cultured in $\alpha$-MEM/10\% FBS containing $0.1 \%$ DMSO (v/v) (Sigma, D2650). Then, the cultures were washed with PBS, the medium in each well was replaced with $100 \mu \mathrm{l}$ of FBS-free $\alpha$-MEM, and 10\% CCK-8 working solution was added. The mixture was incubated for $1 \mathrm{~h}$ at $37{ }^{\circ} \mathrm{C}$ in a humidified atmosphere of $5 \% \mathrm{CO}_{2}$ and measured at $450 \mathrm{~nm}$ using a microplate reader. The cells in the control group were cultured in $\alpha$-MEM containing $0.1 \%$ DMSO.

\section{Reverse transcription-quantitative polymerase chain reaction}

After being treated with LPZ for $24 \mathrm{~h}$, total RNA was extracted from MC3T3-E1 cells with TRIzol reagent (Thermo Fisher, 15596018). Subsequently, the concentration of RNA in the samples was determined by a TECAN Grating-type multifunctional microplate detector, and the target ratio was between 1.8 and 2.0. Next, RNA was reverse transcribed into cDNA under the following reaction conditions: $37{ }^{\circ} \mathrm{C}$ for $15 \mathrm{~min}, 85^{\circ} \mathrm{C}$ for $5 \mathrm{~s}$, and $4{ }^{\circ} \mathrm{C}$ for $5 \mathrm{~min}$. Then, the samples were stored at $-20{ }^{\circ} \mathrm{C}$ for future use. Polymerase chain reaction conditions were set as follows: $95{ }^{\circ} \mathrm{C}$ for $10 \mathrm{~min}$ to predenature the sample; and $95{ }^{\circ} \mathrm{C}$ for $15 \mathrm{~s}$ and $60{ }^{\circ} \mathrm{C}$ for $1 \mathrm{~min}$ to alternate for 40 cycles. GAPDH was used as an internal reference, and the fold change value was used to express the relative gene expression. The primers used in this study are listed in Table 1.

\section{Quantification of apoptosis using flow cytometry}

Cell apoptosis was examined by Annexin V-FITC and PI staining (Vazyme, A211-02). MC3T3-E1 cells were treated with LPZ $(5,10,20,50 \mu \mathrm{M})$ for $12 \mathrm{~h}$. After being treated, the cells were washed with precooled PBS twice. The cells were digested with $0.25 \%$ trypsin (without EDTA) and then centrifuged, and the centrifuged cells were washed twice with PBS. Then, $500 \mu \mathrm{l}$ of Annexin V binding solution, $5 \mu \mathrm{l}$ of Annexin V-FITC staining solution, and $5 \mu \mathrm{l}$ of propidium iodide (PI) were added to each tube of cells. Cells in the control group were treated with only binding solution but not 
Table 1 Primers sequence for PCR

\begin{tabular}{lll}
\hline Genes & Forward $\left(\mathbf{5}^{\prime} \mathbf{-} \mathbf{3}^{\prime} \mathbf{)}\right.$ & Reverse $\left.\mathbf{( 3}^{\prime} \mathbf{-} \mathbf{5}^{\prime}\right)$ \\
\hline OCN & AGACTCCGGCGCTACCTTGG & CGGTCTTCAAGCCATACTGGTCTG \\
ALP & TCATTCCCACGTTTTCACATTC & GTTGTTGTGAGCGTAATCTACC \\
COLIa & GCTCCTCTTAGGGGCCACT & CCACGTCTCACCATTGGGG \\
Runx2 & ATGCTTCATTCGCCTCACAAA & GCACTCACTGACTCGGTTGG \\
Caspase-12 & TGGCCCATGAATCACATCTAAT & TGGACAAAGCTTCAGTGTATCT \\
ATF4 & TGGCTGGCTGTGGATGG & TCCCGGAGAAGGCATCCT \\
GAPDH & GGTTGTCTCCTGCGACTTCA & TGGTCCAGGGTTTCTTACTCC \\
ATP2B1 & AGATGGAGCTATTGAGAATCGCA & CCCTGTAACACGGATTTTTCCTT \\
\hline
\end{tabular}

with staining solution. Double labeling was performed at room temperature for $10 \mathrm{~min}$ in the dark before flow cytometric analysis. The cells in the control group were cultured in normal medium containing 0.1\% DMSO.

\section{Cellular calcium analysis}

$\left[\mathrm{Ca}^{2+}\right]_{\mathrm{i}}$ was measured using the calcium-sensitive fluorescent indicator fluo-3/AM (Keygen Biotech, KGAF023-1). MC3T3-E1 cells were cultured in confocal dishes and loaded with $5 \mu \mathrm{M}$ fluo-3AM for $30 \mathrm{~min}$ in Hank's balanced salt solution (HBSS) (Gibco, C14175500BT). Then, the cells were washed gently three times with HBSS, incubated with calciumcontaining HBSS (Gibco, 24020-133) or calcium-free HBSS and examined by real-time under laser confocal microscopy (Zeiss, LSM 5) within $1 \mathrm{~h}$; recording started when the fluorescence intensity of the cells stabilized. Cells were then promptly treated with LPZ, 2-APB (ApexBio, B6643), ryanodine (ApexBio, B5092), thapsigargin (TG) (Sigma, T9033), verapamil (ApexBio, B1687), and BTP-2 (ApexBio, B7542). Mag-fluo-4/AM (AAT Bioquest, 20401) is a fluorescent probe that labels endoplasmic reticulum $\mathrm{Ca}^{2+}\left(\left[\mathrm{Ca}^{2+}\right]_{\mathrm{ER}}\right)$, and Rhod-2/ AM (ApexBio, C3276) is a fluorescent probe that labels mitochondrial $\mathrm{Ca}^{2+}\left(\left[\mathrm{Ca}^{2+}\right]_{\text {mit }}\right)$ with bright and stable fluorescence. Next, MC3T3-E1 cells were loaded with $2.5 \mu \mathrm{M}$ Mag-Fluo-4-AM plus $2 \mu \mathrm{M}$ ER-tracker (Beyotime, C1041) or $5 \mu \mathrm{M}$ Rhod-2 AM plus MitoTracker green $(1 \mu \mathrm{M})$ (Beyotime, C1048) for $20 \mathrm{~min}$ at room temperature to examine changes in ER and mitochondrial $\mathrm{Ca}^{2+}$. Changes in the fluorescence intensity of the indicator represent changes in the $\mathrm{Ca}^{2+}$ concentration. In addition, changes in calcium after longterm drug treatment were analyzed by flow cytometry. The cells in the control group were cultured in normal medium containing $0.1 \%$ DMSO. The calcium responses were semiquantified by measuring the area under the curve
(AUC) using GraphPad Prism 8 (Luptak et al. 2018; Peterson et al. 2019).

Patch clamp measurement of sodium-calcium exchangers The electrode was made of hard glass with a microelectrode puller (HEKA). The resistance value of the electrode was 4-8 M $\Omega$. The electrode was filled with water. Single cells with neat edges, no particles on the surface and no contraction are selected. The three-dimensional manipulator was adjusted to move the tip of the electrode to the cell surface, and slight negative pressure was applied. After a high resistance seal formed, fast capacitance was compensated, and negative pressure was applied to break the cell membrane and form a whole cell mark in recording mode. All experiments were carried out at room temperature $\left(25{ }^{\circ} \mathrm{C}\right)$. The stimulation parameters were as follows: constant $-40 \mathrm{mV} 250 \mathrm{~ms}$, ramp $60 \mathrm{mV} 1000 \mathrm{~ms}$, ramp - $140 \mathrm{mV} 2000 \mathrm{~ms}$, ramp $-40 \mathrm{mV} 1000 \mathrm{~ms}$, and constant $-40 \mathrm{mV} 250 \mathrm{~ms}$. After recording the $\mathrm{I}_{\mathrm{NCX}}$ current of the cells, the $\mathrm{I}_{\mathrm{NCX}}$ current was stable for $10 \mathrm{~min}$, and the prepared test drug solution was administered so that the final drug concentration in the cell pool was $0,10,50$, and $100 \mu \mathrm{M}$ in turn, which was stable for 20 min after each administration, and the $\mathrm{I}_{\mathrm{NCX}}$ current of the cells was recorded after the drug diffusion became uniform.

\section{Western blot analysis}

MC3T3-E1 cells were treated with $0.1 \%$ DMSO (the vehicle group), $10 \mu \mathrm{M}$ LPZ, $25 \mu \mathrm{M} 2-\mathrm{APB}$, and $2 \mu \mathrm{M}$ TG for $24 \mathrm{~h}$. Whole proteins were extracted using RIPA buffer and then denatured for $10 \mathrm{~min}$ at $95{ }^{\circ} \mathrm{C}$. Equal amounts of protein $(10 \mu \mathrm{g})$ were separated on a $10-12 \%$ SDS-PAGE gel and transferred to PVDF (Merck Millipore, ISEQ00010) membranes. The membrane was rinsed and blocked with 5\% nonfat milk in TBST at room temperature for $2 \mathrm{~h}$ and then incubated overnight at $4{ }^{\circ} \mathrm{C}$ with specific primary antibodies against Grp78 
(Servicebio, GB11098), CHOP (Cell Signaling, L63F7), Caspase-12 (CST, 2202), Calpain-2 (Abcam, ab126600), cleaved-Caspase-3 (CST, 9661), ATF4 (SAB, 32007), OPG (BTL3466), Rankl (BTL5404T), ALP (Proteintech, 11187-1-AP), OCN (SAB, 23319), GAPDH (SAB, 21612), Actin $\beta$ (BTL338), Bax (Proteintech, 50599-2-lg), Bcl-2 (ab59348), and Cyt (Servicebio, GB11080). Then, the membranes were washed 3 times for $10 \mathrm{~min}$ with TBST and incubated with horseradish peroxidase (HRP)-conjugated anti-rabbit secondary antibodies (Servicebio, GB23303) for $1 \mathrm{~h}$ at room temperature. The membranes were washed 3 times for 10 min with TBST, and the blots were visualized with enhanced chemiluminescence reagents and analyzed with ImageJ software.

\section{Statistical analysis}

Measurement data are expressed as the mean \pm SD. One-way ANOVA followed by Tukey's test was used for comparisons among groups, and $P<0.05$ was considered statistically significant $\left({ }^{*} P<0.05,{ }^{* *} P<0.01\right)$.

\section{Results}

Effect of LPZ on bone density, serum biochemical indices and femoral biomechanical properties in mice

After continuous gavage administration for 6 months, there was no significant difference in body weight among the groups. Compared with the CMC-Na group, the lowdose group and high-dose group showed dose-dependent decreasing trends in the material mechanical parameters maximum bone load (maximum breaking force) and bone structure strength (maximum crushing force) in femoral samples (Fig. 1A, B). Furthermore, the lowdose group $(250 \mathrm{mg} / \mathrm{kg})$ and high-dose group $(1000 \mathrm{mg} /$ $\mathrm{kg}$ ) showed decreasing trends in femoral BMD, and there was a significant difference between the control group and high-dose group (Fig. 1C). Bone serum biochemical analysis showed that serum ALP (S-ALP) decreased slightly and serum calcium ( $\mathrm{S}-\mathrm{Ca}$ ) and serum phosphorus (S-IP) decreased significantly (Fig. 1D-F). Similarly, compared with that in the CMC-Na group, the trabecular bone microarchitecture was thin and loose (Fig. 2).

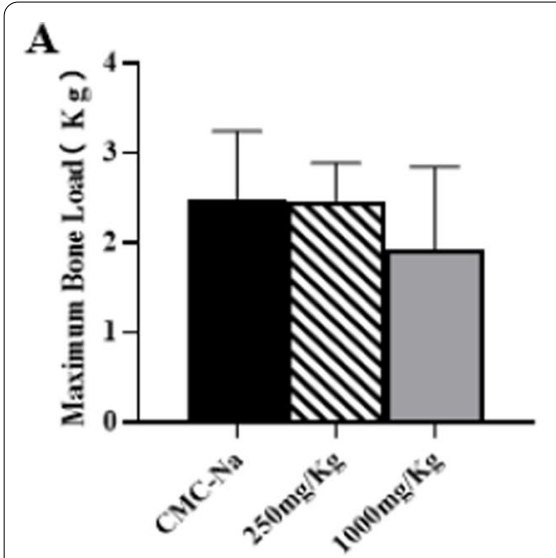

B

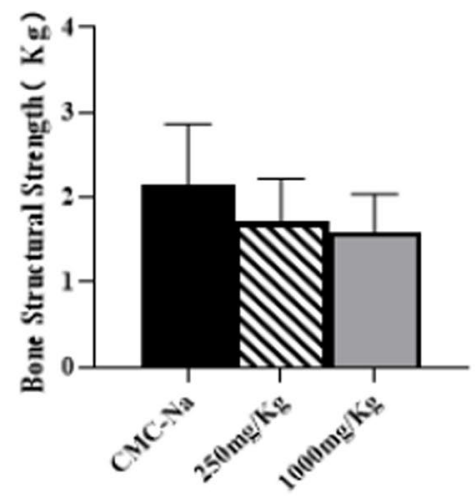

D

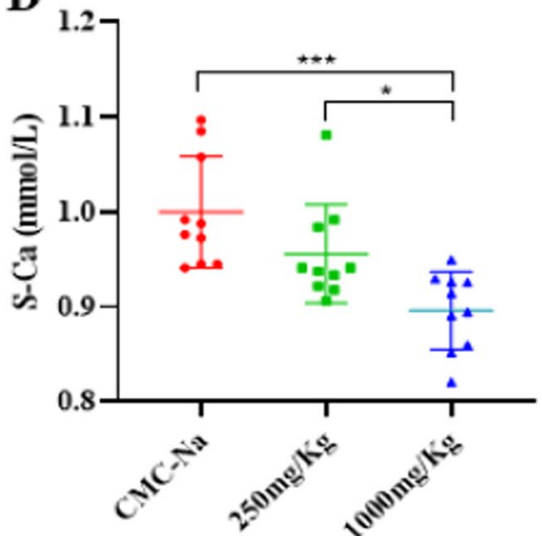

$\mathbf{E}$

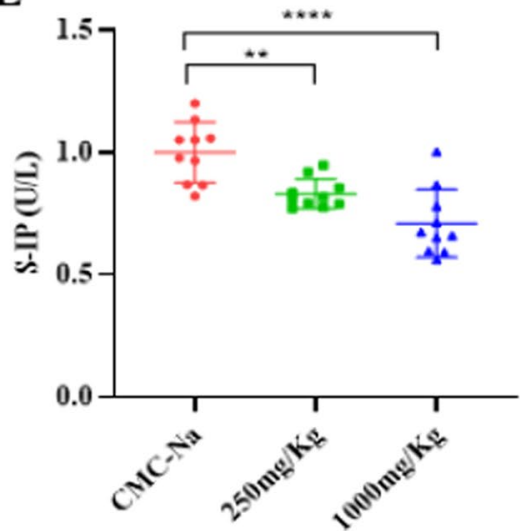

C

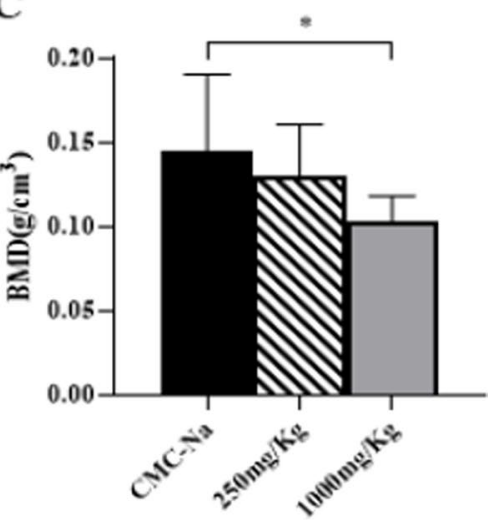

$\mathbf{F}$

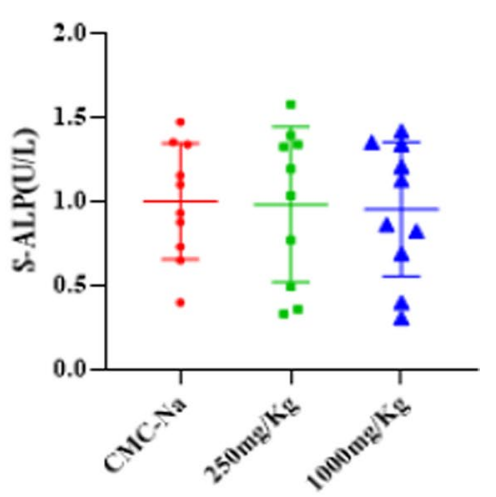

Fig. 1 After 6 months of LPZ gavage, the right femurs of male and female mice were scanned by micro-CT to calculate BMD ( $n=10$ ); the remaining mice were randomly sacrificed, and blood was collected to examine bone and serum biochemical indicators $(n=10)$. A, B Femoral biomechanical strength properties. C BMD of the right femur. D-F Bone serum biochemical parameters 


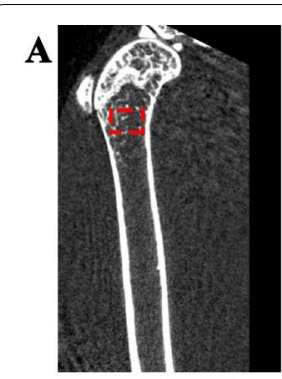

CMC-Na

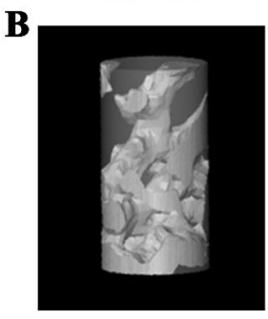

CMC-Na

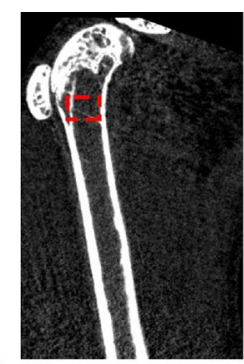

$250 \mathrm{mg} / \mathrm{Kg}$

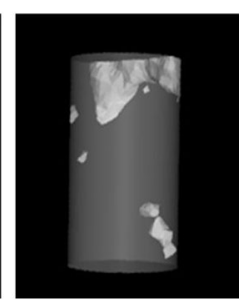

$250 \mathrm{mg} / \mathrm{Kg}$

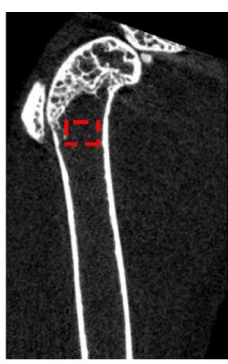

$1000 \mathrm{mg} / \mathrm{Kg}$

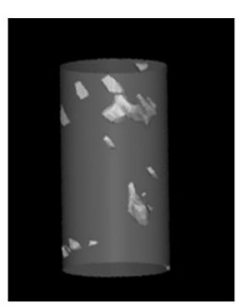

$1000 \mathrm{mg} / \mathrm{Kg}$
Fig. 2 Representative microcomputed tomography (micro-CT) images of the distal femurs. A Micro-CT images of femur specimens showed a reduction in trabecular bone microarchitecture after treatment with increasing doses of LPZ (red box). B Micro-CT images of cancellous bone structures near the growth plate $(n=7)$

\section{Effect of LPZ on MC3T3-E1 cell viability}

After discovering that LPZ damaged mouse bone tissue, MC3T3-E1 cells, a common osteoblast cell line, was used to explore the mechanism by which LPZ causes bone damage. First, we used EdU assays to determine whether LPZ promoted or inhibited MC3T3-E1 cell proliferation. The proportion of proliferating cells decreased significantly $(P<0.05)$ when cells were treated with LPZ at concentrations of $5,10,20$, and $50 \mu \mathrm{M}$ (Fig. 3A, C). Next, we further explored whether LPZ could injure MC3T3E1 cells through an apoptotic mechanism. MC3T3-E1 cells were incubated in $\alpha$-MEM $/ 10 \%$ FBS containing different concentrations $(0,5,10,20$, and $50 \mu \mathrm{M})$ of LPZ. The apoptosis rate in the LPZ treatment group increased in a dose-dependent manner (Fig. 3B, D). Furthermore, LPZ inhibited the viability of MC3T3-E1 cells in a dosedependent manner, as determined by a CCK- 8 assays (Fig. 3E). These results suggested that LPZ inhibited the viability of MC3T3-E1 cells, leading to apoptosis.

\section{Calcium responses after LPZ treatment in MC3T3-E1 cells LPZ increased calcium through $E R \mathrm{Ca}^{2+}$ release}

We used confocal laser scanning microscopy to investigate calcium real-time changes in MC3T3-E1 cells after LPZ treatment. We found that calcium fluorescence significantly increased in MC3T3-E1 cells treated with $50 \mu \mathrm{M} \mathrm{LPZ} \mathrm{(Fig.} \mathrm{4A).} \mathrm{Moreover,} \mathrm{the} \mathrm{increase} \mathrm{in}$ $\left[\mathrm{Ca}^{2+}\right]_{\mathrm{i}}$ was slightly higher in the calcium-containing solution than in calcium-free solution (Fig. 4B). BAPTA is a calcium chelator that can prevent the increase in calcium fluorescence after administration, but there was no significant difference between the two groups (Fig. $4 \mathrm{C}$ ), which indicated that $\left[\mathrm{Ca}^{2+}\right]_{\mathrm{i}}$ originated from both intracellular calcium release and extracellular calcium influx and that intracellular calcium release was mainly required for the LPZ-induced $\left[\mathrm{Ca}^{2+}\right]_{\mathrm{i}}$ response in MC3T3-E1 cells. Thapsigargin (TG) is an inhibitor of SERCA with high specificity. MC3T3-E1 cells were pretreated with TG in calcium-free solution to deplete calcium stores in the ER and then treated with $50 \mu \mathrm{M} \mathrm{LPZ}$, and there was no change in calcium in MC3T3-E1 cells (Fig. 4D). These findings suggested that LPZ-mediated calcium signaling in MC3T3-E1 cells was mainly mediated by ER $\mathrm{Ca}^{2+}$ release. In addition, we preincubated the cells with BAPTA/AM to chelate intracellular free $\mathrm{Ca}^{2+}$ and found that MC3T3-E1 cell survival was significantly increased $(P<0.05)$. LPZ inhibited the viability of MC3T3-E1 cells; however, the viability of MC3T3-E1 cells that were preincubated with BAPTA/AM was significantly higher than that of MC3T3-E1 cells that were not preincubated with BAPTA/AM, which indicated that the $\left[\mathrm{Ca}^{2+}\right]_{\mathrm{i}}$ increase was an important factor in LPZ-induced cell damage and that BAPTA/AM could effectively protect cell viability by blocking this process (Fig. 4E).

\section{LPZ-induced calcium increases through the IP3R and SOCE pathways}

Cells were preincubated with 2-APB $(25 \mu \mathrm{M})$ or ryanodine $(20 \mu \mathrm{M})$ in calcium-free medium, blocking the IP3R $\mathrm{Ca}^{2+}$ release channel or $\mathrm{Ryr} \mathrm{Ca}^{2+}$ release channel, respectively. Then, the cells were treated with $10 \mu \mathrm{M} \mathrm{LPZ}$ (clinically relevant concentrations). Ryanodine had little effect on $\left[\mathrm{Ca}^{2+}\right]_{i}$ activation by LPZ (Fig. 5B), but 2-APB altered the calcium fluorescence intensity to be consistent with that in the vehicle group (Fig. 5A). In addition, to confirm which calcium channel was responsible for calcium influx, MC3T3-E1 cells were preincubated with verapamil $(10 \mu \mathrm{M})$, an L-type calcium channel blocker (Jung et al. 2015), or BTP-2 $(20 \mu \mathrm{M})$, a store-operated calcium (SOC) channel blocker, in calcium-containing medium and then treated with $10 \mu \mathrm{M}$ LPZ. BTP-2 partly restrained the increase in calcium fluorescence (Fig. 5D); however, verapamil had little effect on $\left[\mathrm{Ca}^{2+}\right]_{\mathrm{i}}$ (Fig. $5 \mathrm{C}$ ). Taken together, these results suggested that LPZ inhibited SERCA in the ER membrane, leading to $\mathrm{Ca}^{2+}$ release from the ER through the IP3R channel and promoting the activation of SOCE. 


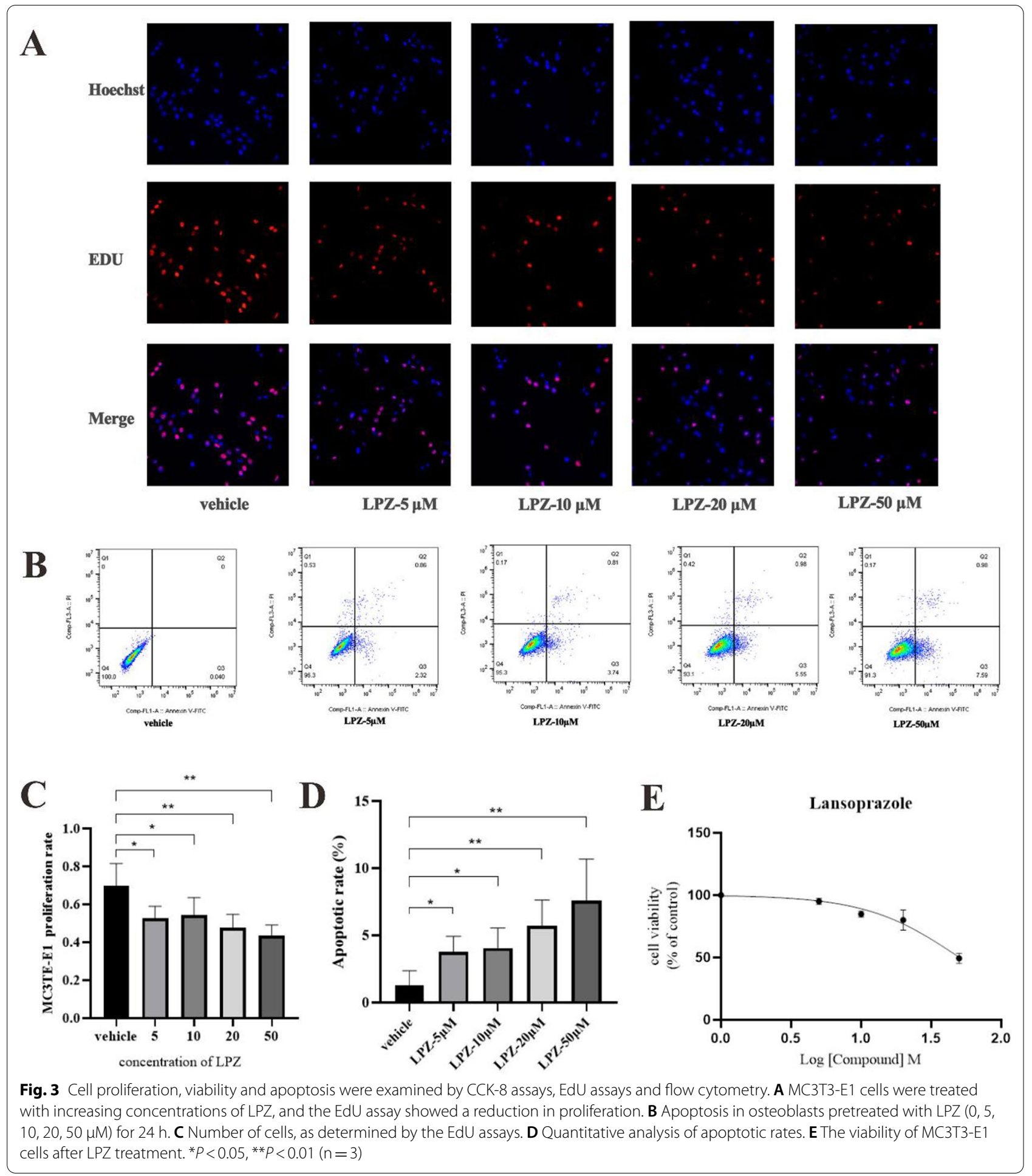

$L P Z$ decreased $\left[\mathrm{Ca}^{2+}\right]_{\mathrm{ER}}$ and increased $\left[\mathrm{Ca}^{2+}\right]_{\text {mito }}$

Furthermore, to investigate whether LPZ had an effect on the ER and mitochondria, MC3T3-E1 cells were loaded with Mag-fluo4/AM and Rhod-2/AM probes to identify calcium levels in the ER and mitochondria, respectively.
As expected, ER $\mathrm{Ca}^{2+}$ fluorescence decreased after LPZ $(10 \mu \mathrm{M})$ was added, while $\mathrm{Ca}^{2+}$ in mitochondria slightly increased (Fig. 6). These results indicated that $\mathrm{Ca}^{2+}$ was released from the ER and flowed into nearby mitochondria. 


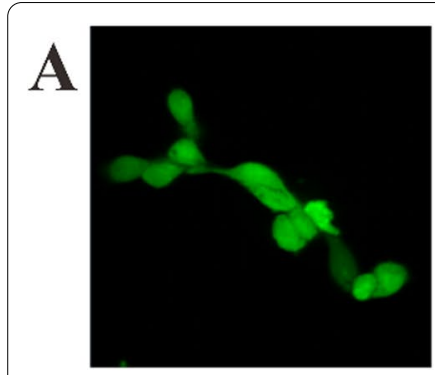

$0 \mathrm{~s}$

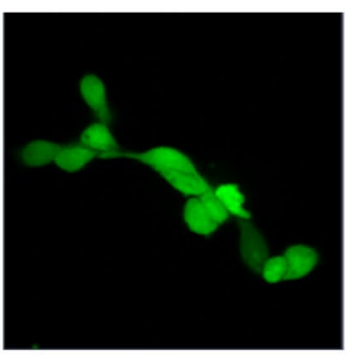

$50 \mathrm{~s}$

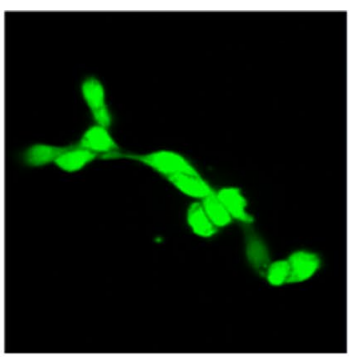

$100 \mathrm{~s}$

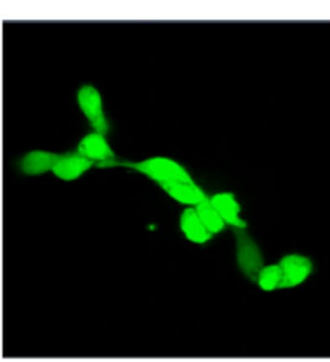

$150 \mathrm{~s}$

B
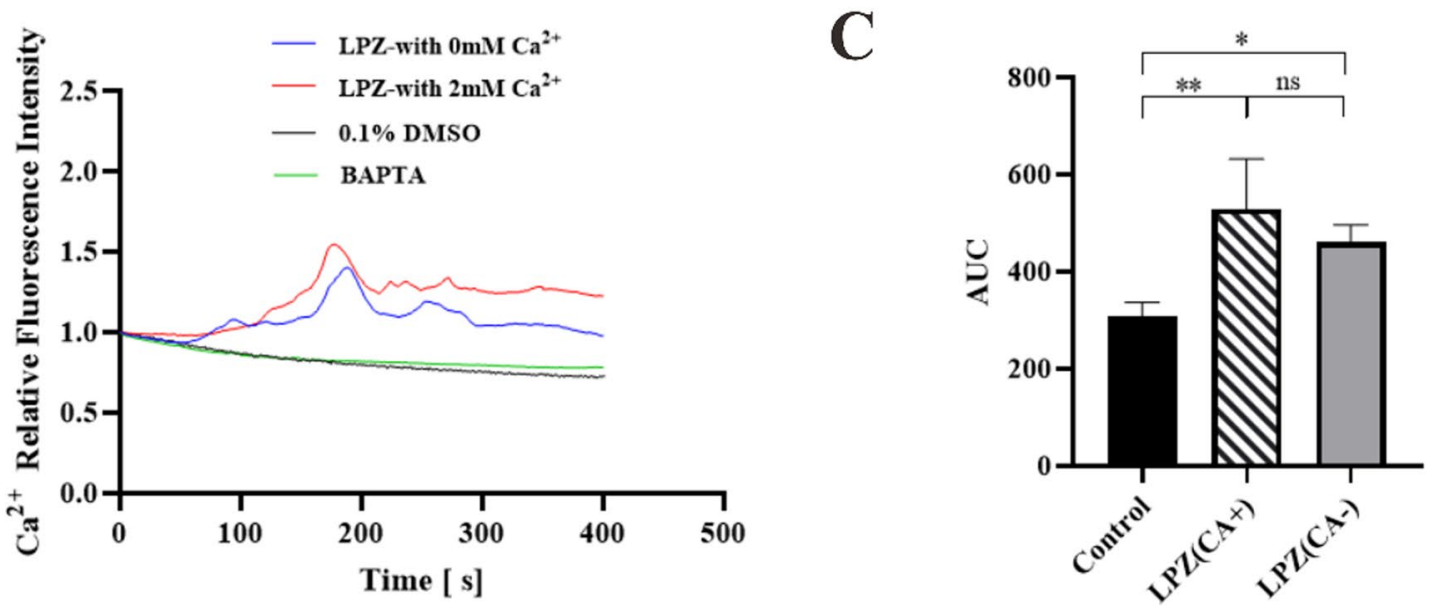

D

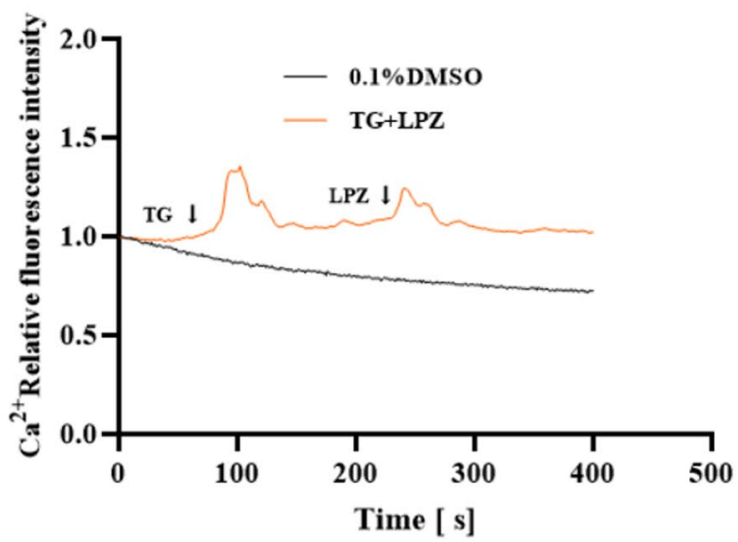

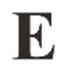

$\mathbf{E}$

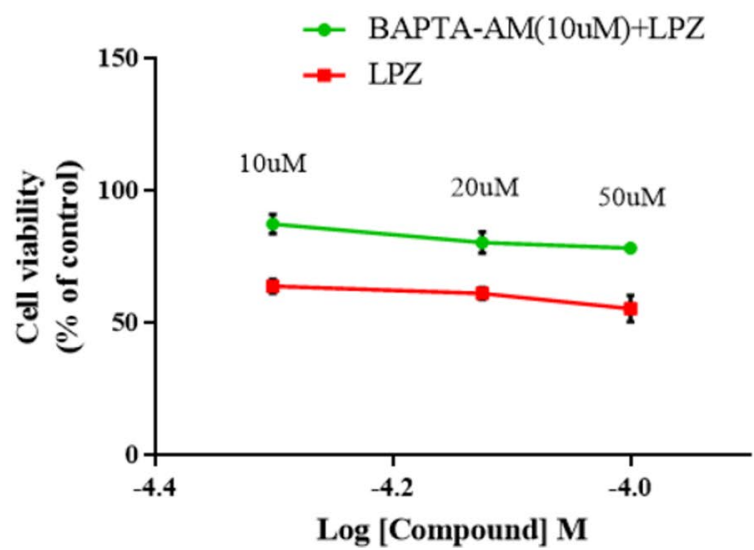

Fig. 4 Calcium regulation in MC3T3-E1 cells was observed by confocal microscopy. A Representative confocal images (40 x): After LPZ administration, intracellular calcium fluorescence increased significantly. B Quantification of Fluo-3 fluorescence: $\mathrm{Ca}^{2+}$ fluorescence was slightly higher with calcium than without calcium. C Area under the curve of Fluo-3 fluorescence: There was no significant difference in the area under the curve of calcium fluorescence with or without calcium. D Fluo-3 fluorescence after preincubation with TG $(n=3)$ : After preincubation with TG to deplete calcium stores, LPZ did not cause a significant increase in cellular calcium fluorescence. EThe viability of MC3T3-E1 cells after preincubation with BAPTA/AM and LPZ treatment with CCK-8: BAPTA prevented the increase in $\mathrm{Ca}^{2+}$ and could effectively protect cell viability

\section{Flow cytometric assessment of calcium}

\section{Elevated calcium in long-term LPZ-exposed MC3T3-E1 cells}

Then, we used flow cytometry to investigate changes in intracellular calcium after longterm treatment $(24 \mathrm{~h})$ with LPZ in MC3T3-E1 cells. MC3T3-E1 cells were preincubated with TG $(2 \mu \mathrm{M})$ in calcium-free medium or preincubated with BTP-2 $(20 \mu \mathrm{M})$ in calcium-containing medium. Then, LPZ was added to MC3T3-E1 cells 

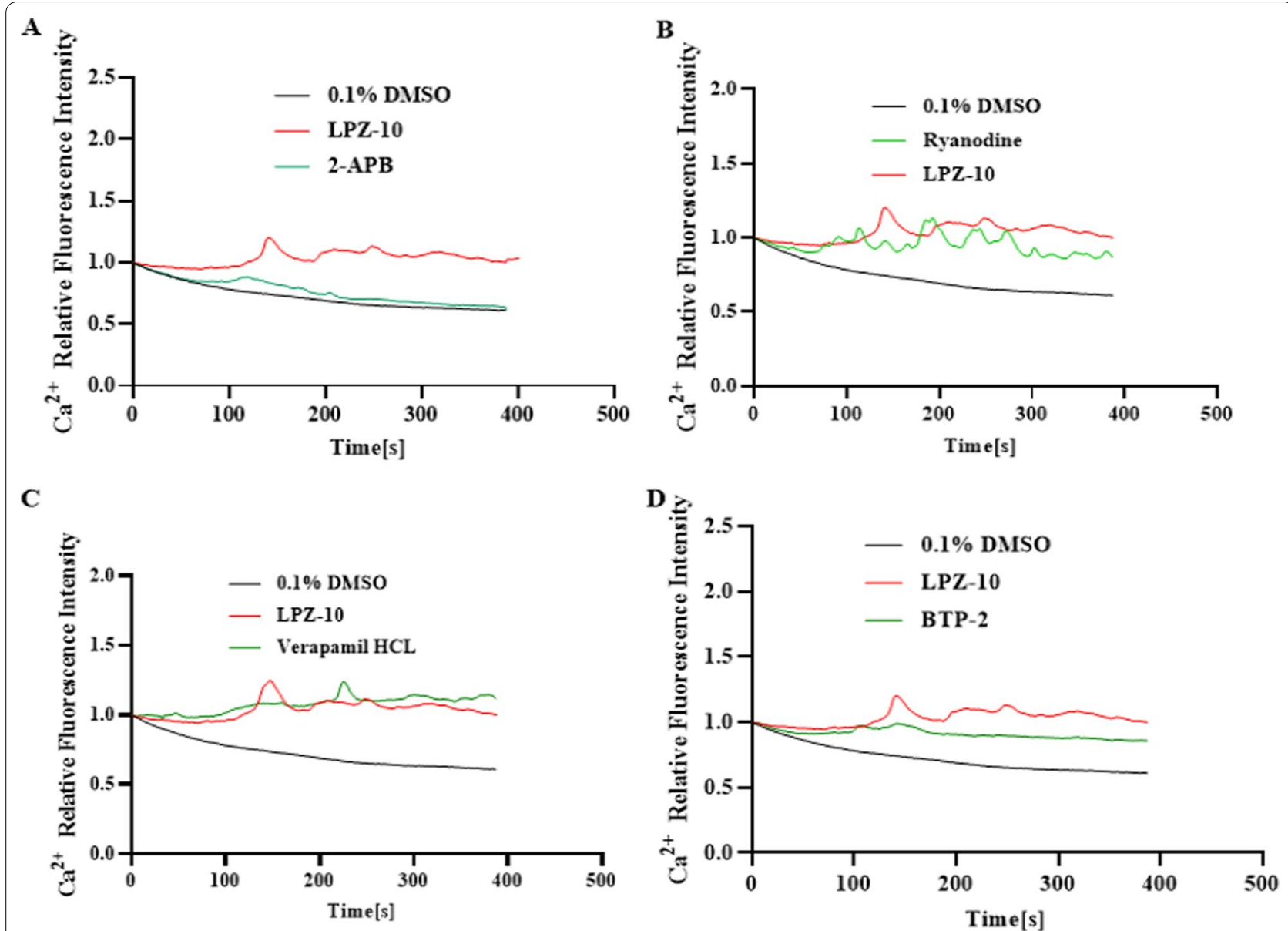

Fig. 5 Relative calcium fluorescence change curves. A Relative $\left[\mathrm{Ca}^{2+}\right]_{i}$ response in MC3T3-E1 cells that were preincubated with 2-APB in Ca ${ }^{2+}-f$ ree medium. B Relative $\left[\mathrm{Ca}^{2+}\right]_{j}$ response in MC3T3-E1 cells that were preincubated with ryanodine in $\mathrm{Ca}^{2+}$-free medium. $\mathbf{C}$ Relative $\left[\mathrm{Ca}^{2+}\right]_{i}$ response in MC3T3-E1 cells that were preincubated with verapamil in $\mathrm{Ca}^{2+}$-containing medium. $\mathbf{D}$ Relative $\left[\mathrm{Ca}^{2+}\right]_{\mathrm{i}}$ response in MC3T3-E1 cells that were preincubated with BTP-2 in $\mathrm{Ca}^{2+}$-containing medium $(\mathrm{n}=3)$

and incubated for $1 \mathrm{~h} .\left[\mathrm{Ca}^{2+}\right]_{\mathrm{i}}$ was significantly higher in calcium-containing or calcium-free medium than in the vehicle group (0.1\% DMSO). Furthermore, the magnitude of the calcium increase in MC3T3-E1 cells that were preincubated with BTP-2 in calcium-containing conditions was not significantly different from that in MC3T3-E1 cells that were treated with LPZ in calciumfree conditions. However, taking the vehicle as a reference, the increase in $\left[\mathrm{Ca}^{2+}\right]_{i}$ was significantly lower when MC3T3-E1 cells were preincubated with TG under calcium-free conditions $(P<0.01)$ (Fig. 7). These results were consistent with our confocal microscopy results; the main source of $\mathrm{Ca}^{2+}$ was intracellular $\mathrm{Ca}^{2+}$, and extracellular $\mathrm{Ca}^{2+}$ accounted for only a small amount.

\section{$\left[\mathrm{Ca}^{2+}\right]_{\mathrm{i}}$ remained high in MC3T3-E1 cells after LPZ exposure}

We used TG $(2 \mu \mathrm{M})$ and LPZ $(50 \mu \mathrm{M})$ in calcium-containing medium, and incubated the cells for $24 \mathrm{~h}$. The intracellular calcium level remained high in the LPZ group, but the intracellular calcium level was low in the TG group, and there was no significant difference between the TG and vehicle groups. When MC3T3-E1 cells were treated with $\mathrm{TG}$, the $\left[\mathrm{Ca}^{2+}\right]_{i}$ did not remain at a high level for a long time, and $\mathrm{Ca}^{2+}$ was expelled by PMCA and NCX on the plasma membrane over time. However, LPZ could maintain $\left[\mathrm{Ca}^{2+}\right]_{\mathrm{i}}$ at a high level for a long time, and LPZ might inhibit calcium efflux transporters. These results suggest that LPZ might have an inhibitory effect on SERCA and/or PMCA. $\mathrm{Ca}^{2+}$ stress seems to be associated with longterm stress conditions; thus, longterm $\mathrm{Ca}^{2+}$ overload may induce apoptosis. We hypothesized that LPZ might inhibit PMCA and/or NCX 


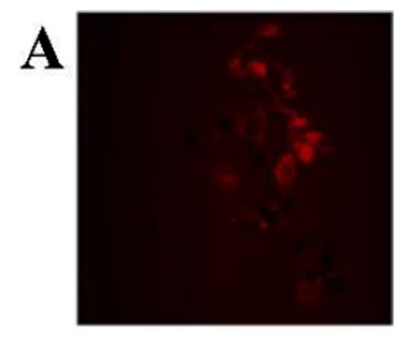

Mito-Ca ${ }^{2+}$

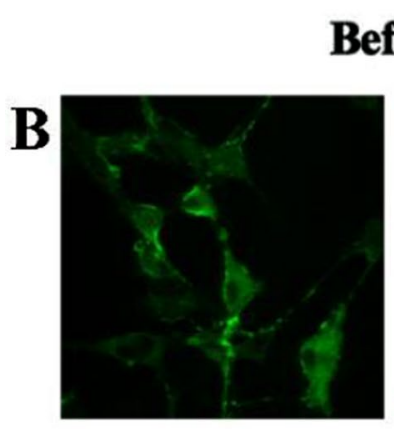

$\mathrm{ER}_{\mathbf{C a}}{ }^{2+}$

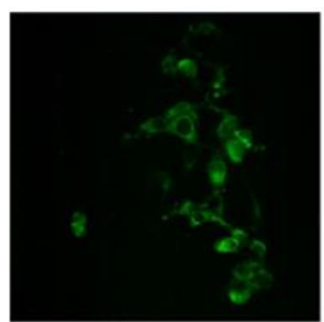

Mito-tracker

Before

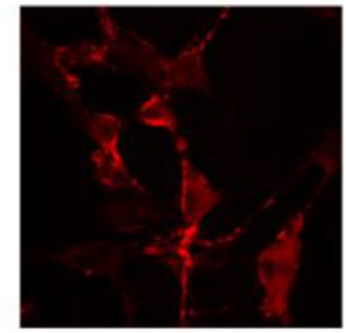

ER-Traker

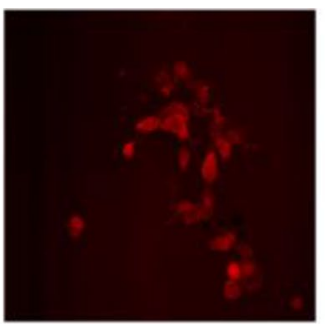

Mito-Ca ${ }^{2+}$

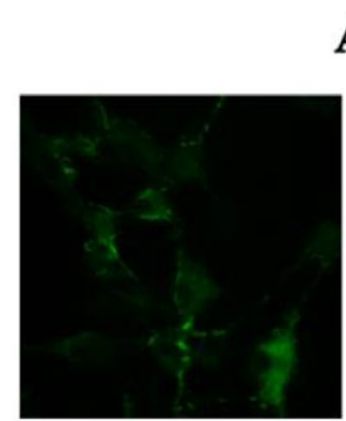

ER-Ca ${ }^{2+}$

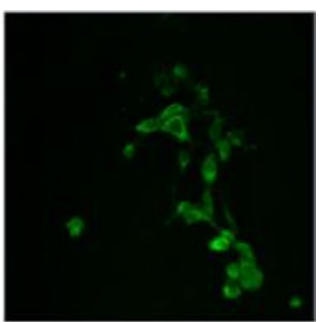

Mito-tracker

After

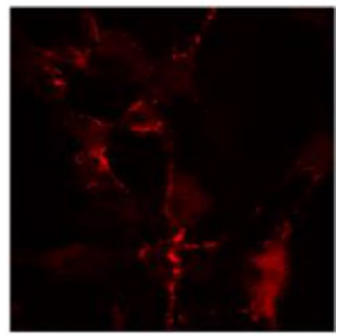

ER-Traker

Before

After

Fig. 6 Representative confocal images of MC3T3-E1 cells. A MC3T3-E1 cells were double-loaded with ER tracker (red) and Mag-fluo4/AM (green) to determine ER Ca ${ }^{2+}$ levels. B MC3T3-E1 cells were double-loaded with MitoTracker Green and Rhod-2AM (red) to determine mitochondrial Ca ${ }^{2+}$ levels. $(20 \times)$

and that $\mathrm{Ca}^{2+}$ cannot be discharged, which explains why the LPZ-treated groups remained calcium overloaded after 24 h (Fig. 8) $(n=3)$.

\section{NCX current changes}

In osteoblasts, PMCA and NCX are responsible for calcium balance. We examined the effect of LPZ on NCX transporters using the patch clamp technique. It was shown that $10 \mu \mathrm{M} \mathrm{LPZ}$ increased the reverse current density from $-3.29 \pm 1.00 \mathrm{pA} / \mathrm{PF}(0 \mu \mathrm{M})$ to $-5.62 \pm 1.46$ $\mathrm{pA} / \mathrm{pF}$ by $70.91 \%$; the current density was $-18.9 \pm 5.96$ $\mathrm{pA} / \mathrm{pF}$ by $475.10 \%$ at $50 \mu \mathrm{M}$, and the current density of $100 \mu \mathrm{M}$ was $-5.21 \pm 2.33 \mathrm{pA} / \mathrm{pF}$ by $58.52 \%$ at $100 \mu \mathrm{M}$ (Fig. 9). Taken together, the patch clamp results showed that 10,50 , and $100 \mu \mathrm{M}$ lansoprazole could significantly strengthen the reverse current (forward mode) of the $\mathrm{Na}^{+}-\mathrm{Ca}^{2+}$ exchange current in MC3T3-E1 cells $(P<0.05)$. This result indicated that at concentrations of 10,50 , and $100 \mu \mathrm{M} \mathrm{LPZ}, \mathrm{Ca}^{2+}$ could be transported out through $\mathrm{Na}^{+}-\mathrm{Ca}^{2+}$ exchangers. Based on this finding, patch clamp analysis showed that LPZ could concentrationdependently enhance $\mathrm{Ca}^{2+}$ transport through $\mathrm{Na}^{+}-\mathrm{Ca}^{2+}$ exchangers in MC3T3-E1 cells. We hypothesized that lansoprazole might stimulate $\mathrm{Ca}^{2+}$ overload to prompt an increase in sodium-calcium exchanger activity to maintain a low intracellular calcium level.

\section{Effects of LPZ on MC3T3-E1 mRNA expression levels}

MC3T3-E1 cells were treated with 0.1\% DMSO (the vehicle group), $10 \mu \mathrm{M}$ LPZ, $25 \mu \mathrm{M} 2-\mathrm{APB}$, and $2 \mu \mathrm{M}$ TG for $24 \mathrm{~h}$, and then we examined the effects of LPZ on genes related to differentiation and the ER stress apoptosis pathway in MC3T3-E1 cells. We found that LPZ could reduce the mRNA expression levels of differentiating and mature MC3T3-E1 cells (ALP, OCN, Runx2, CoLI $\alpha$ ) and increase the mRNA expression levels of ER stress markers (Caspase12, ATF4) (Fig. 10).

\section{Expression of ERS and osteoblast functional protein}

Previous studies have reported that Caspase-12, GRP78, ATF4, and CHOP are mediators of ERS, Bcl-2 is an antiapoptotic protein, and Bax is a proapoptotic protein (Chiu et al. 2018). TG can induce rapid calcium release from the ER and promote ER stress. We treated the TG group as a positive control group (Chen et al. 2021). In this study, compared with those in the vehicle group, LPZ increased ERS-mediated Caspase-12, Grp78, ATF4, and CHOP protein levels and promoted the expression of cleaved caspase-3, a terminal cleavage enzyme, during apoptosis. However, preincubation with 2-APB reduced ER stress 


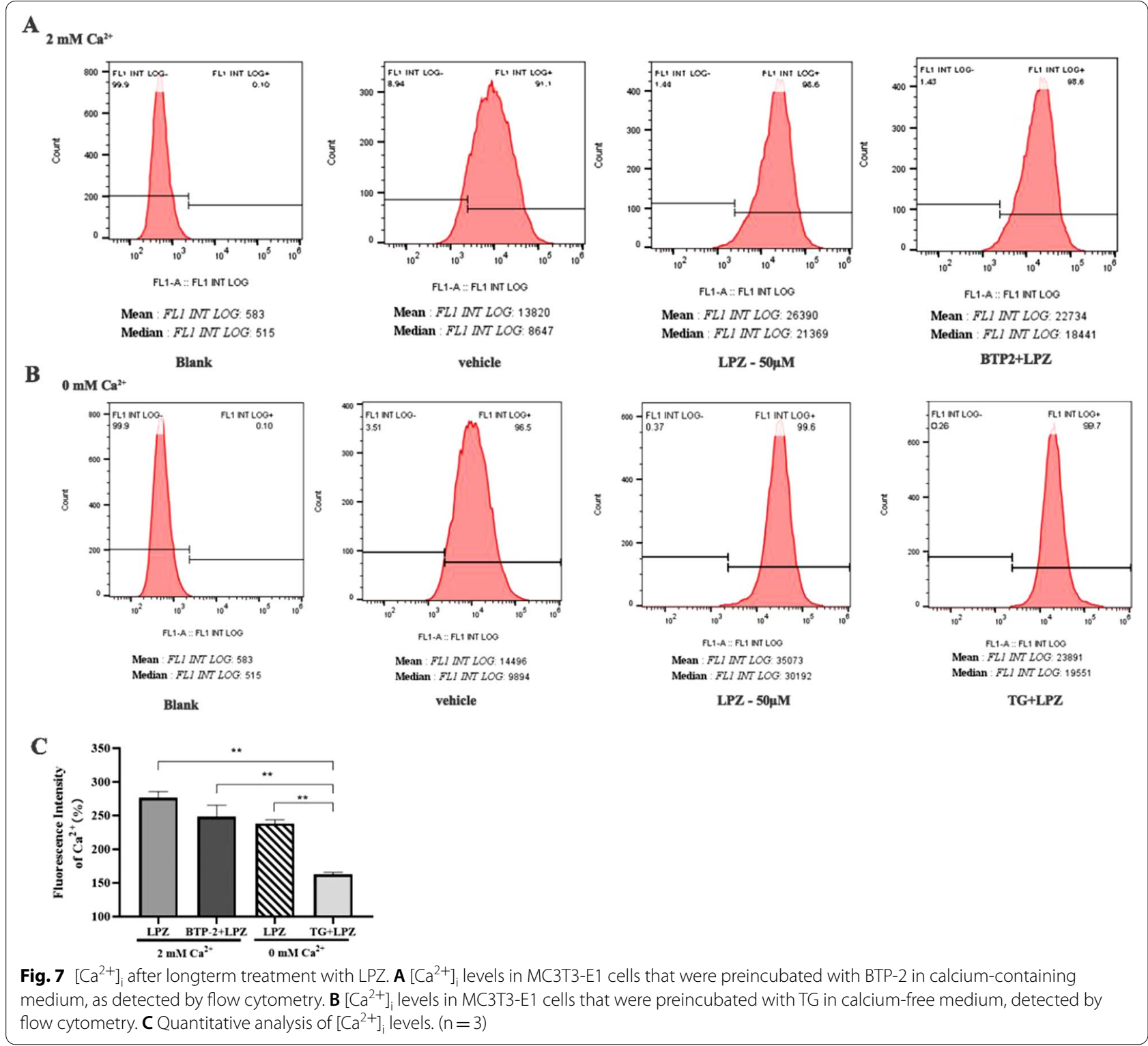

protein expression and abrogated the increase in the $\mathrm{Bax} / \mathrm{BCL}-2$ ratio induced by LPZ. It is well documented that $\mathrm{Bcl}-2$ also regulates endoplasmic reticulum calcium homeostasis (Chiu et al. 2018). Moreover, the expression of Calpain-2, a calcium-dependent ER stress protein, was upregulated in the LPZ and TG groups, and 2-APB alleviated the expression of Calpain-2, which meant that LPZ increased intracellular calcium and ER stress. Moreover, the expression levels of MC3T3-E1 osteoblast functional proteins ALP, OPG/Rankl, OCN were reduced in the LPZ group and the TG group compared with the vehicle group, which illustrated that LPZ could induce ERS in MC3T3-E1 cells in a dose-dependent manner, impair the function of MC3T3-E1 osteoblasts, and affect differentiation, secretion, and mineralization, and 2-APB could protect the viability of MC3T3-E1 cells after the treatment of LPZ for $24 \mathrm{~h}$. (Fig. 11).

\section{Ca-ATPase activity assay}

Furthermore, the activity of the Ca-ATP enzyme in MC3T3-E1 cells was examined by phosphorus assays, and the results showed that the activity of the $\mathrm{Ca}$ ATP enzyme was decreased in the LPZ group (Fig. 12). After treatment with $10 \mu \mathrm{M} \mathrm{LPZ}$, the expression of the $\mathrm{Ca}^{2+}$-ATP enzyme (ATP2B1) in the plasma membrane decreased in a time-dependent manner. Although the kit measured the activity of all Ca-ATP enzymes, it also provided some reference for us. These results suggested that 


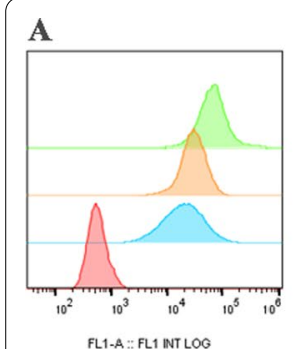

B

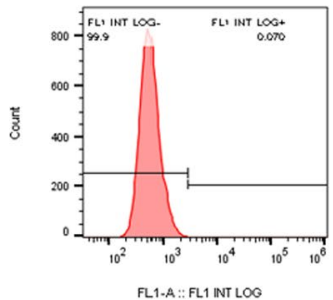

Mean : FLL INT LOG: 606 Median : FLI INT LOG: 540

Blank

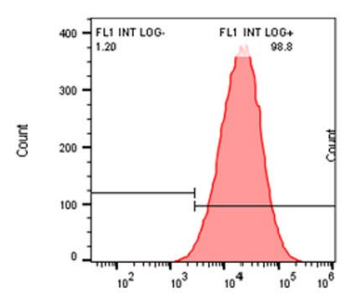

FL1-A:F FL1 INT LOO

Mean : FL1 INT LOG: 26178 Median : FLI INT LOG: 19402

Vehicle

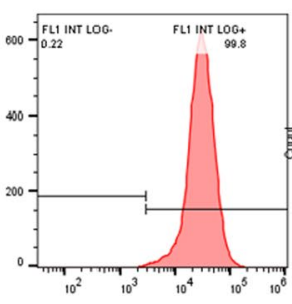

FL1-A : FL1 INT LOG

Mean : FLI INT LOG: 32860 Median : FLI INT LOG: 29062

TG-2 $\mu \mathrm{M}$

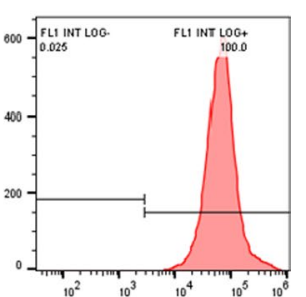

FL1.A: FL1 NT LOG
: LLI INT LOG: 79591 Median :FLI INT LOG: 64548

LPZ-50 $\mu \mathrm{M}$

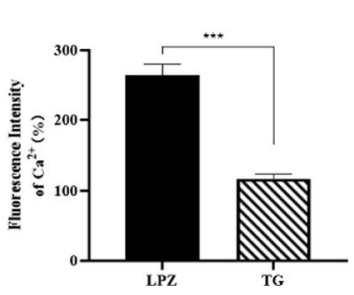

Fig. $8\left[\mathrm{Ca}^{2+}\right]_{i}$ after longterm treatment with LPZ and TG. A $\left[\mathrm{Ca}^{2+}\right]_{\mathrm{i}}$ levels in MC3T3-E1 cells that were preincubated with TG in calcium-containing medium, as detected by flow cytometry. B Quantitative analysis of $\left[\mathrm{Ca}^{2+}\right]_{i}$ after treatment with LPZ or TG for $24 \mathrm{~h}(\mathrm{n}=3)$

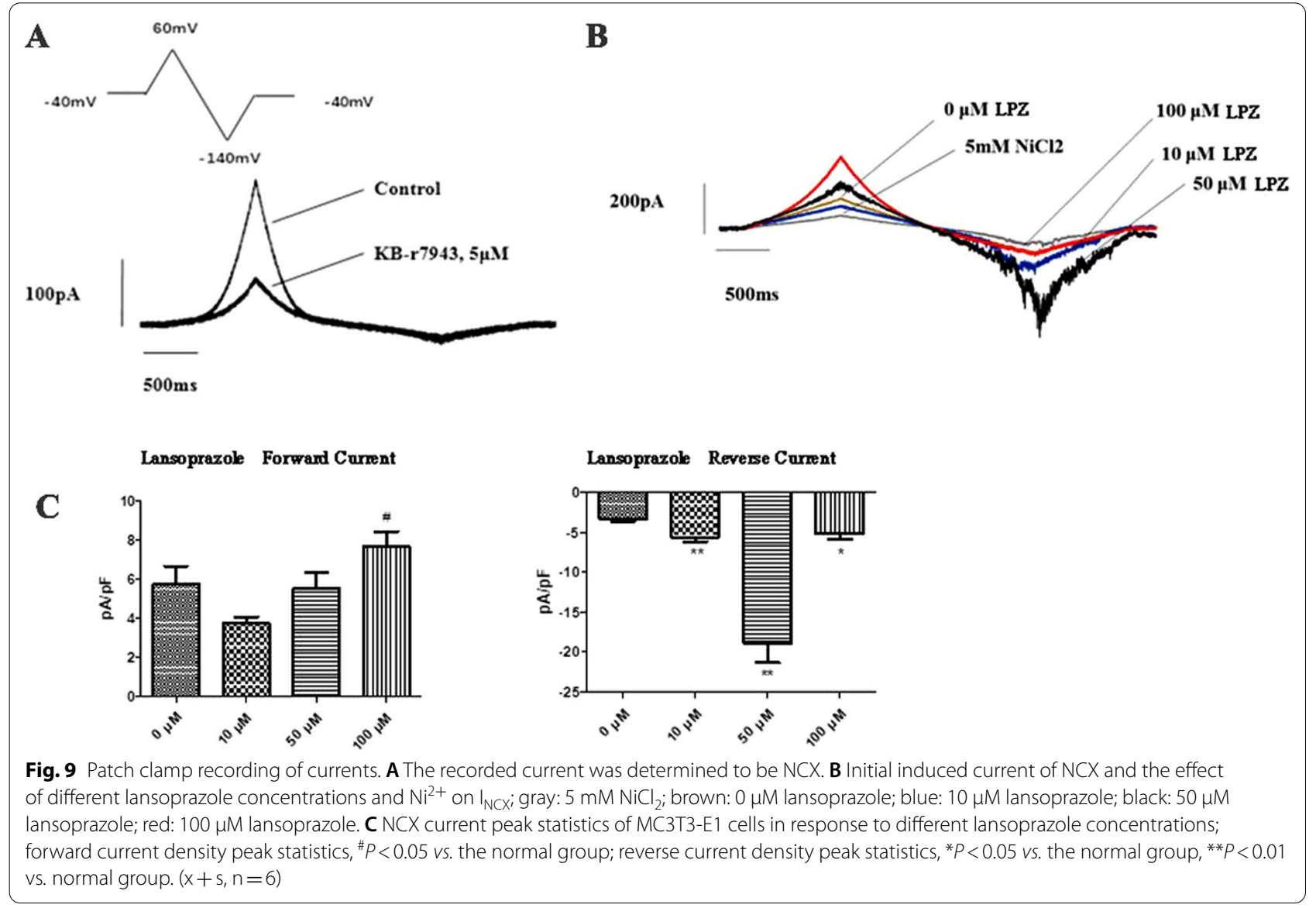




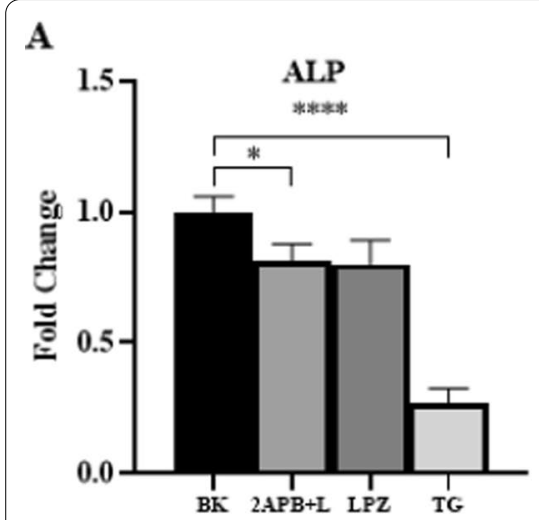

D

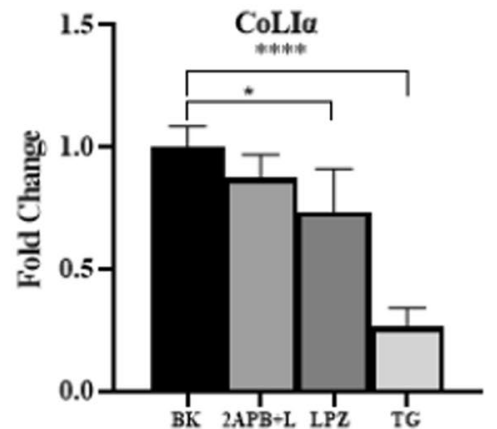

B

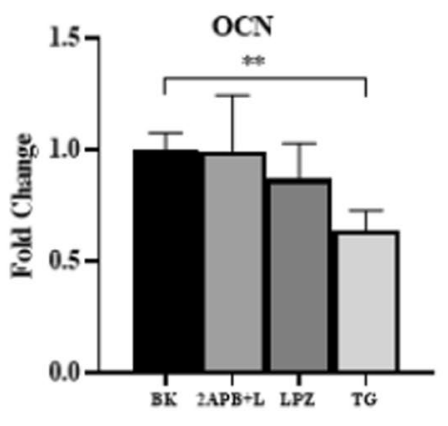

$\mathbf{E}$

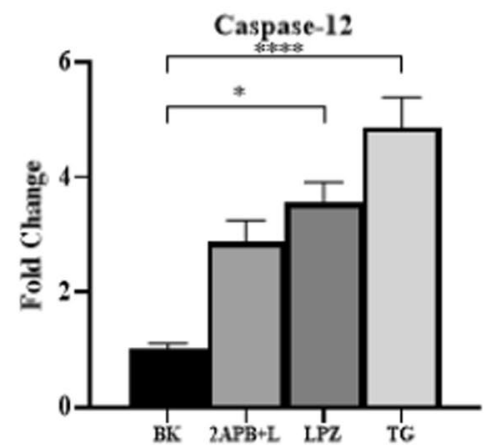

C

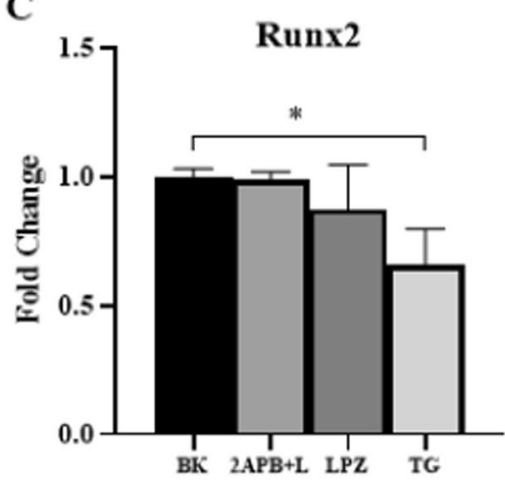

$\mathbf{F}$

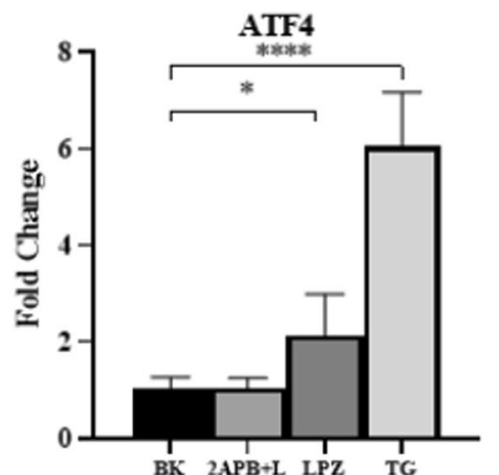

Fig. 10 The mRNA expression of OB functional genes and ER stress and apoptosis pathway-related genes (ALP, OCN, Runx2, COLIa, Caspase-12, ATF4). TG was used as a positive control $(n=3)$

LPZ had a negative effect on the calcium pump activity of MC3T3-E1 cells.

\section{HE staining and immunohistochemical staining in bone}

In vivo, HE staining showed that in the control group, the trabecular bone microstructure was dense, with full cancellous bones and few vacuoles. In the low-dose group, trabecular bone was loosely arranged and partially broken, with a decrease in thickness and some vacuoles in the bone marrow. In the high-dose group, trabecular bone was fractured, thinner and had worsened structural integrity, increased separation and more vacuoles in the medulla (Fig. 13A). To examine whether ERS occurred in mice, we used immunohistochemical staining to measure the expression of CHOP, an ER stress marker, in the distal femurs of the different groups. The immunohistochemical results showed that after longterm intragastric administration, the expression of $\mathrm{CHOP}$ gradually increased with increasing LPZ doses $(P<0.05)$. It was suggested that longterm LPZ administration may have a negative effect on bone tissue and cause ER stress in the distal femur (metaphysis). Osteoblasts on the trabecular bone surface were also decreased, influencing bone remodeling. This result indicated that endoplasmic reticulum stress occurred in the bone tissues of mice (Fig. 13B, C). In conclusion, the in vivo and in vitro experiments showed that LPZ could lead to increased apoptosis in bone cells and bone injury through endoplasmic reticulum stress.

\section{Discussion}

Here, we hypothesized that LPZ could inhibit the P-type ATPases SERCA and PMCA, leading to an increase in $\mathrm{Ca}^{2+}$ in osteoblasts and inducing endoplasmic reticulum stress and apoptosis, and blocking the increase in intracellular calcium had a significant protective effect against osteoblast apoptosis. The increase in osteoblast apoptosis resulted in osteoporosis after 6 months of LPZ administration, which was characterized by an increase in bone microstructure destruction and a decrease in BMD. Therefore, our study suggested that LPZ was a clinical drug, and longterm use of this drug in patients with bone damage may provide a reference for the rational use of such drugs. 


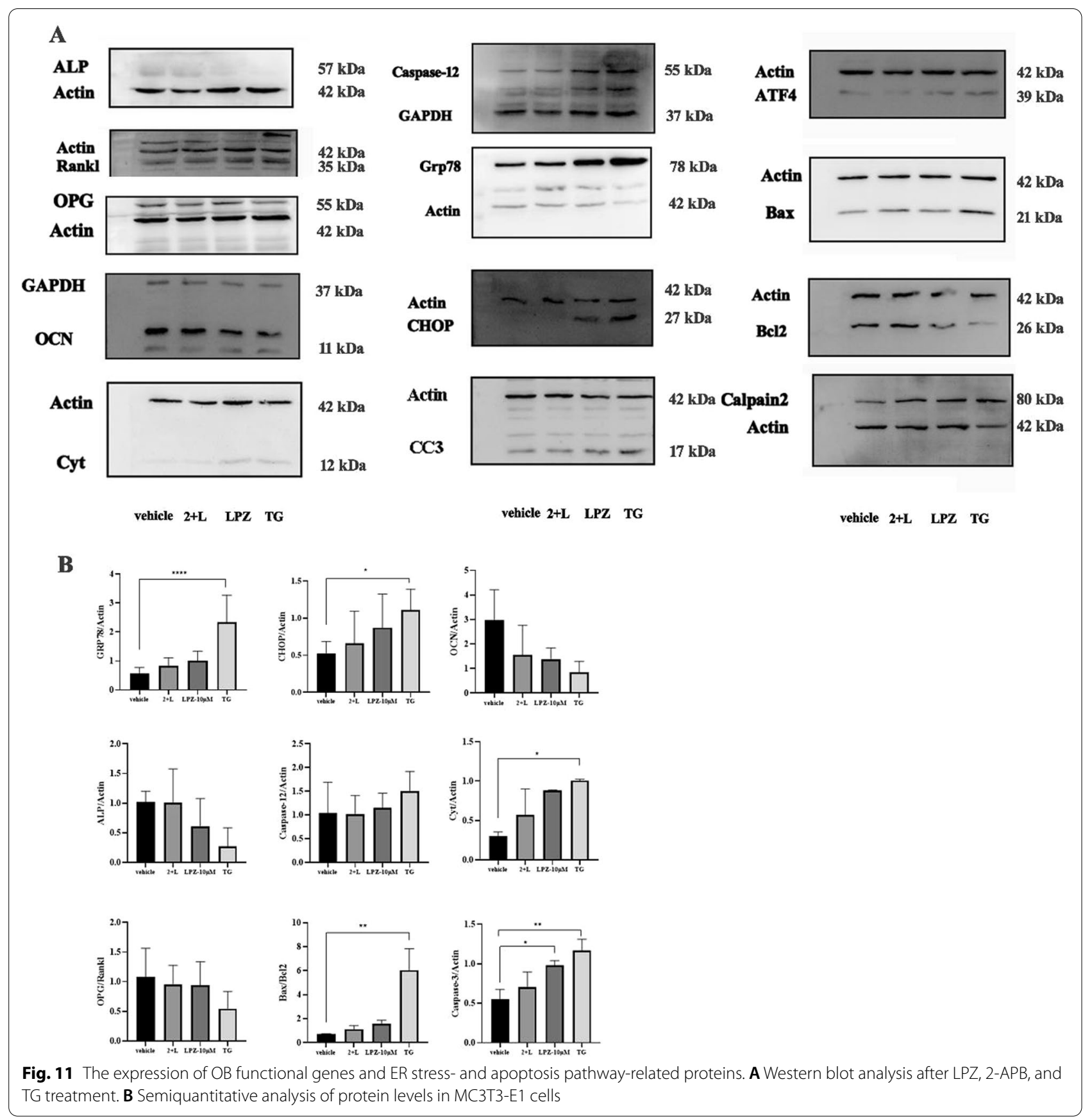

In our previous studies, we were able to identify peak plasma concentrations of LPZ in mice that aligned with those observed in response to routine clinical doses (Sun et al. 2017). Prolonged treatment with low and high doses of LPZ led to reductions in BMD and bone structural strength in mice, although there were no changes to overall health, as indicated by consistent body weight during treatment. These results suggested that longterm use of LPZ could influence the balance of bone metabolism and microstructural damage to bone tissue in mice in vivo. The HE staining results showed the morphological structure of trabecular bone in the distal femoral metaphysis (Liu et al. 2017). There was an obvious morphological difference between the control group and the LPZ groups.

Subtle alterations in calcium signaling regulation could cause significant changes in the physiological functions of osteoblasts. Previous studies have shown that changes in calcium can affect the proliferation of MC3T3-E1 

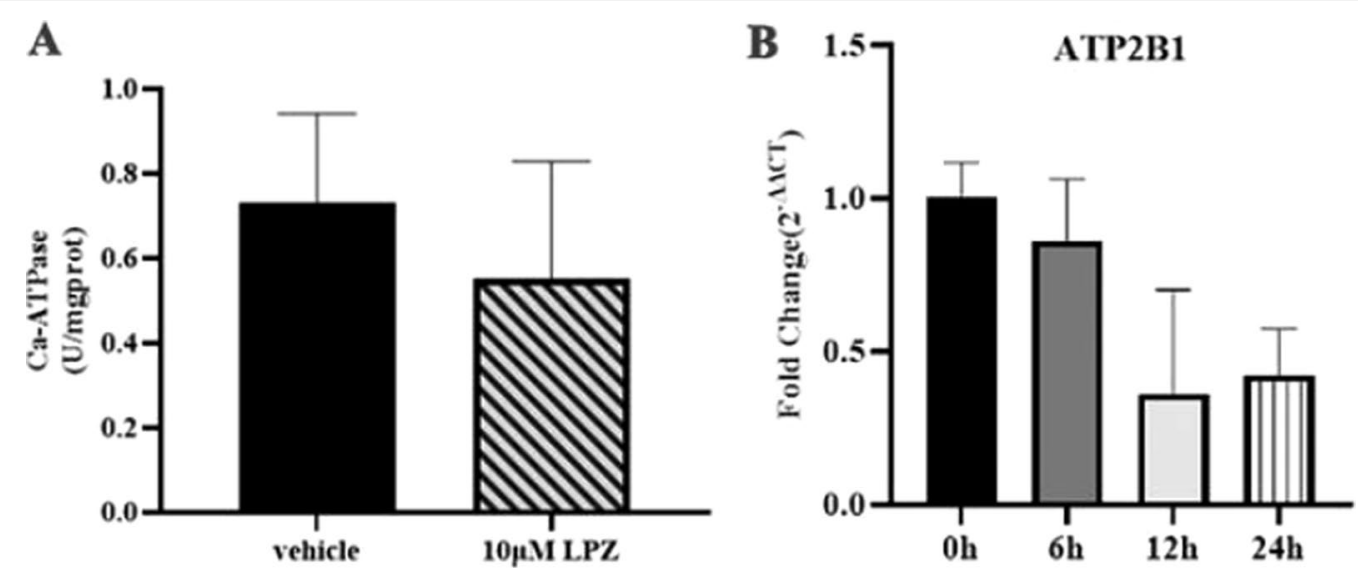

Fig. 12 Effects of LPZ on Ca ${ }^{2+}$-ATPase in MC3T3-E1 cells. A LPZ reduced Ca ${ }^{2+}$-ATPase activity. B LPZ inhibited plasma membrane Ca ${ }^{2+}$-ATPase gene expression $(n=3)$

cells (Liu et al. 2008; Yu et al. 2018). In vitro, LPZ stimulated $\mathrm{Ca}^{2+}$ release in OBs, and BAPTA-AM rescued the increased MC3T3-E1 cell apoptosis triggered by LPZ, suggesting that the increased $\mathrm{Ca}^{2+}$ levels participated in LPZ-induced OB apoptosis. $\mathrm{Ca}^{2+}$ is an important second messenger, and the precise regulation of $\mathrm{Ca}^{2+}$ by calcium pumps, calcium channels, and sodium-calcium exchangers maintains the normal physiological activities of cells (Krebs et al. 2011). Calpain-2 is a $\mathrm{Ca}^{2+}$-dependent cysteine protease whose activity and function depend on intracellular $\mathrm{Ca}^{2+}$ levels (Bano and Ankarcrona 2018; Wang et al. 2018, 2019). In the present study, LPZ exposure increased the expression of Calpain-2 and Caspase-12 in MC3T3-E1 cells. Caspase-12, which is localized on the cytoplasmic side of the ER membrane, is cleaved and specifically activated during ERS (Zhu et al. 2018; Qiu et al. 2020), illustrating that the increased calcium levels in osteoblasts due to LPZ led to the occurrence of ERS.

Then, we investigated the source of intracellular $\mathrm{Ca}^{2+}$ by flow cytometry and confocal microscopy. It was found that 2-APB could significantly abrogate the increase in $\mathrm{Ca}^{2+}$ fluorescence in calcium-free medium, and BTP-2 could partly restrain the $\left[\mathrm{Ca}^{2+}\right]_{\mathrm{i}}$ increase in calcium-containing medium, suggesting that the $\left[\mathrm{Ca}^{2+}\right]_{i}$ originated from IP3R-mediated ER $\mathrm{Ca}^{2+}$ release and that the SOCE pathway could be the main pathway associated with extracellular $\mathrm{Ca}^{2+}$ influx. Furthermore, we found a slight increase in the red fluorescence of mitochondria, and the green fluorescence value of the ER decreased. It was suggested that LPZ can release ER calcium into the cytoplasm, causing $\mathrm{Ca}^{2+}$ overload, and $\mathrm{Ca}^{2+}$ released into the cytosol by the IP3R channel can be taken up by neighboring mitochondria; a similar mechanism was reported by Filadi and Pizzo (2019).
Previous studies have shown that calcium transport significantly affects the progression of excitotoxicity (Bano and Ankarcrona 2018). We hypothesized that LPZ stimulates $\mathrm{Ca}^{2+}$ overload to increase sodium-calcium exchanger activity and maintain a low intracellular calcium balance (Sosnoski and Gay 2008; Bano and Ankarcrona 2018). PMCA is responsible for calcium efflux in parallel with NCX, and promotion of calcium efflux by NCX might indirectly reflect $\mathrm{Ca}^{2+}$ overload. Furthermore, Liu-zhong Wu et al. found that increased $\mathrm{Ca}^{2+}$ signaling significantly promoted the differentiation of bone marrow mesenchymal stem cells into osteoblasts in the presence of insulin-like growth factor 1 . Osteoblast marker protein expression was significantly increased, and the expression of SERCA and IP3R was also significantly increased. In conclusion, calcium signaling plays an important role in every stage of bone cells, and $\mathrm{Ca}^{2+}$ might not only promote differentiation in bone marrow stem cells but also stimulate apoptosis in osteoblasts (Wu et al. 2020).

Previous studies have confirmed that ER stress plays a key role in the pathogenesis of disuse osteoporosis (Wu et al. 2014; Li et al. 2017). In this study, we also observed increased CHOP expression in mouse tissue in relation to LPZ dose. In addition, the expression of ER stressrelated proteins and osteoblast functional proteins was measured by Western blotting. MC3T3-E1 cells were preincubated with 2 -APB $(20 \mu \mathrm{M})$ to confirm the main pathway associated with the increase in $\left[\mathrm{Ca}^{2+}\right]_{\mathrm{i}}$. 2 -APB has independent targets, including IP3R-dependent ER $\mathrm{Ca}^{2+}$ release and store-operated $\mathrm{Ca}^{2+}(\mathrm{SOC})$ channels in osteoblasts. In this study, we found that LPZ promoted the activation of caspase $12, \mathrm{Bax} / \mathrm{Bcl}-2$, and caspase- 3 induced by ER stress (Wu and Kaufman 2006; Sato et al. 2015; Pihan et al. 2017). Then, we examined some ER 


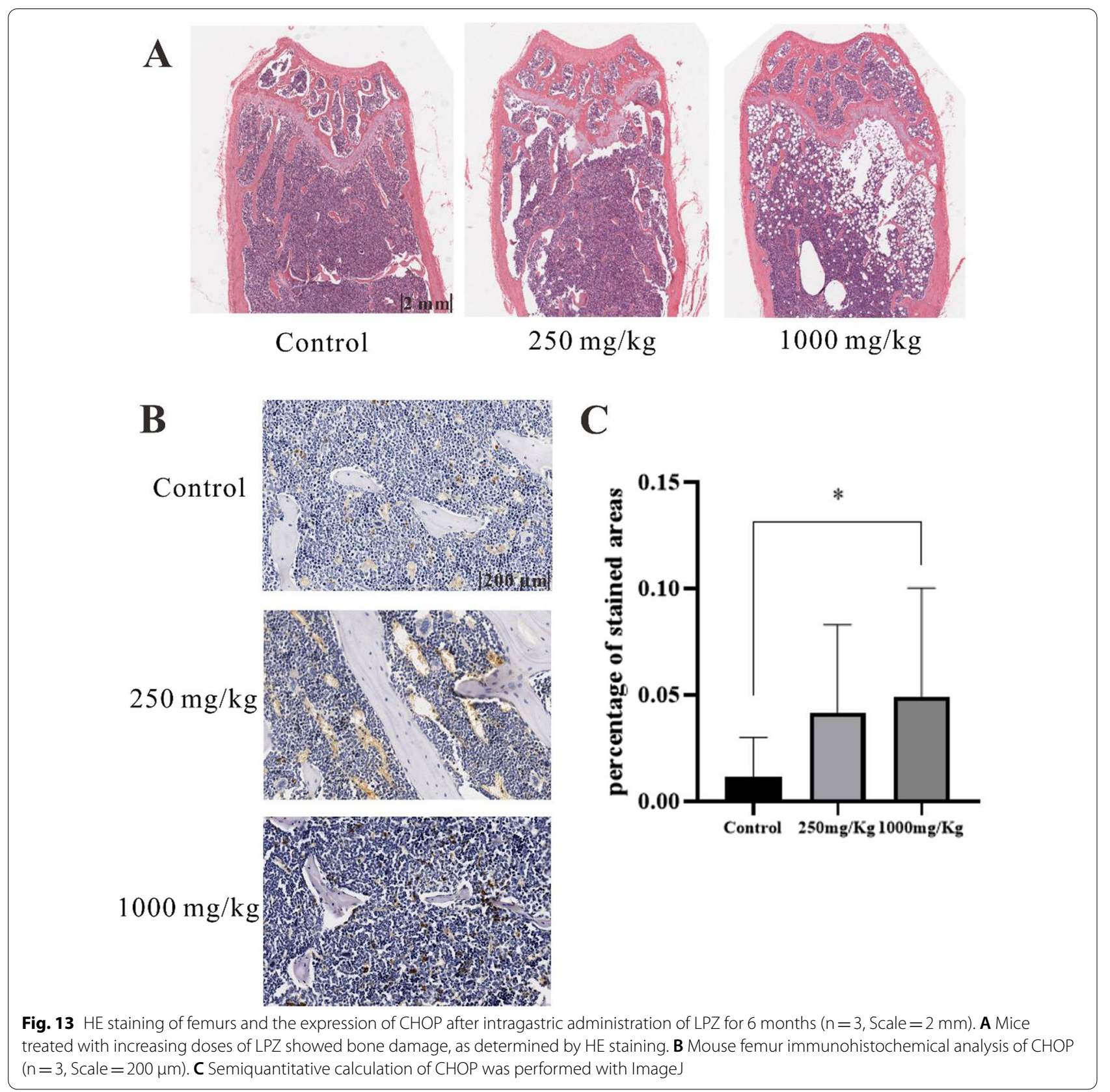

stress markers, including Bip/Grp78, ATF4, and CHOP (Nakamura et al. 2013). We found that LPZ increased the expression of Grp78 and CHOP in MC3T3-E1 cells, which indicated that LPZ caused ER stress in osteoblasts. However, when cells were preincubated with 2-APB, the expression of Grp78, CHOP, caspase-12, Bax/Bcl-2, and caspase- 3 induced by LPZ was suppressed. $\mathrm{Ca}^{2+}$ release from the ER through the IP3R channel and $\mathrm{Ca}^{2+}$ influx via the SOCE pathway contributed to the development of ER stress in osteoblasts (Zhang et al. 2020). Additionally, LPZ treatment was associated with a reduction in the ratio of OPG/Rankl, which has been previously shown to be an indication of bone formation or bone resorption (Tantikanlayaporn et al. 2020). We hypothesized that LPZ may destroy the dynamic balance between $\mathrm{OB}$ bone formation and $\mathrm{OC}$ bone resorption, stimulating bone resorption rather than bone formation. Some animal experiments were consistent with our results and showed that different kinds of PPIs can cause a decrease in the OPG/Rankl ratio at both the cell and animal levels (Fossmark et al. 2012; Hoff et al. 2020). 2-APB rescued the damage to MC3T3-E1 cells induced by LPZ, and the 


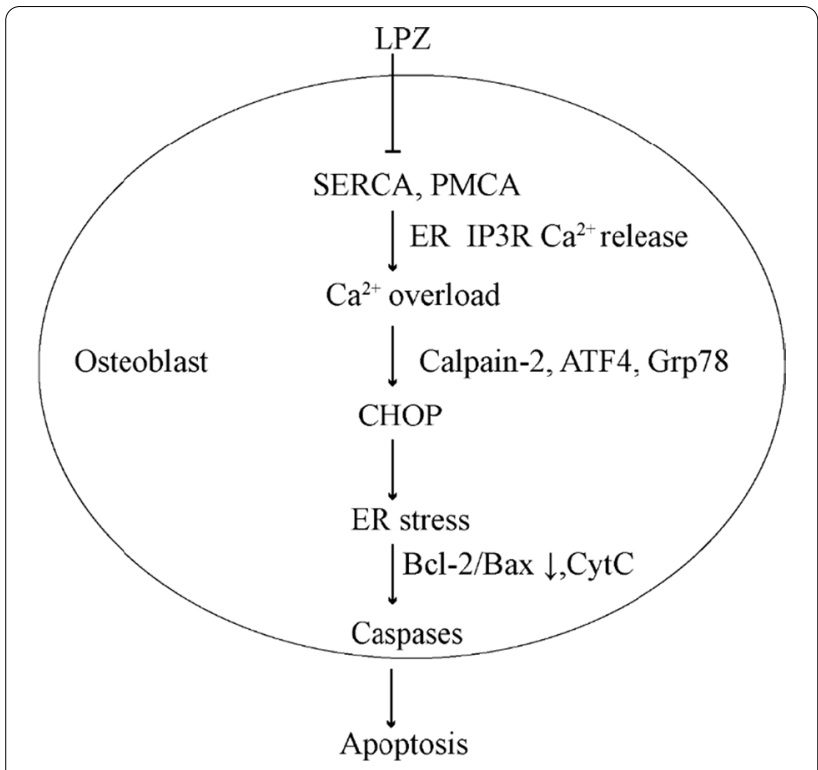

Fig. 14 Possible mechanisms underlying the changes in $\left[\mathrm{Ca}^{2+}\right]_{\mathrm{i}}$

expression of the osteoblastic differentiation markers ALP and OCN was increased (Chou et al. 2005). Calcium signaling is important in bone remodeling and bone healing, and imbalanced $\mathrm{Ca}^{2+}$ homeostasis can affect osteoblast activity and further affect bone formation (Han et al. 2018). Furthermore, we noticed that LPZ treatment enhanced the expression of $\mathrm{CytC}$, suggesting that mitochondrial dysfunction might be a possible mechanism by which LPZ induces apoptosis in MC3T3-E1 cells.

Of course, there are some shortcomings in our research. We only investigated the effects of LPZ on osteoblasts but not osteoclasts. In addition, our study only used MC3T3-E1 cells, and no primary cells were used to confirm the changes in related indicators. Overall, our results highlighted the possible mechanisms of LPZinduced damage to osteoblasts and the significant effects of longterm administration of LPZ on the skeletal system.

\section{Conclusions}

This study was the first to explore LPZ-induced osteoporosis at the local level using changes in $\left[\mathrm{Ca}^{2+}\right]_{\mathrm{i}}$ as an entry point. LPZ inhibited MC3T3-E1 cell viability and triggered significant decreases in BMD and S-Ca, and S-IP levels in mice, inducing osteoporotic symptoms. LPZ could cause persistent increases in the $\left[\mathrm{Ca}^{2+}\right]_{\mathrm{i}}$ mediated by the IP3R and SOCE pathways and promote ER stress by inhibiting PMCA and SERCA, thus promoting apoptosis and ultimately causing a decrease in MC3T3-E1 cell viability and function (Fig. 14). PPIs could disturb $\mathrm{Ca}^{2+}$ homeostasis in the ER, increase $\left[\mathrm{Ca}^{2+}\right]_{\mathrm{I}}$, and activate the
Calpain-2/Caspase-12 and Grp78/ATF4/CHOP pathways, ultimately triggering osteoporosis.

LPZ could enter MC3T3-E1 cells through the cell membrane and inhibit SERCA and PMCA. $\mathrm{Ca}^{2+}$ was released from the endoplasmic reticulum and maintained at a high level, causing calcium toxicity and triggering the endoplasmic reticulum and mitochondrial apoptotic pathways, ultimately leading to a decline in osteoblast activity and function.

\section{Abbreviations \\ PPIs: Proton pump inhibitors; HE: Hematoxylin-Eosin; LPZ: Lansoprazole; OB: Osteoblast; OC: Osteoclast; BMD: Bone mineral density; PMCA: Plasma membrane $\mathrm{Ca}^{2+}$-ATPase; SERCA: Sarcoplasmic reticulum $\mathrm{Ca}^{2+}$-ATPase; TG: Thapsigargin; S-IP: Serum inorganic phosphorus; S-Ca: Serum calcium; S-ALP: Serum alkaline phosphatase; BMD: Bone mineral density; $\left[\mathrm{Ca}^{2+}\right]_{;}$: Intracellular calcium; ERS: Endoplasmic reticulum stress; OC: Osteoclasts; OB: Osteoblasts; BMSCs: Bone mesenchymal stem cells; Grp78: Glucose regulated proteins78; CHOP: C/EBP-homologous protein; ATF4: Activating transcription factor 4; OPG: Osteoprotegerin; ALP: Alkaline phosphatase; OCN: Osteocalcin; GAPDH: Glyceraldehyde-3-phosphate dehydrogenase; Runx2: Runt related transcrip- tion factor 2; COLla: Collagen type I al pha.}

\section{Acknowledgements}

We would like to thank all the colleagues in our research team.

\section{Authors' contributions}

SLN, LY, WYQ contributed to the conception and design of the experiment. Material preparation, data collection, and analysis were performed by MMY, SSY, MZQ, WY, YLY, QXP, ZXH. The first draft of the manuscript was written by CZP. LYJ commented on previous versions of the manuscript. All authors have read and approved the final manuscript.

\section{Funding}

This project was supported by grants from the National Natural Sciences Foundation of China (81673515, 81870436), Natural Science Foundation of Jiangsu Province (BK20161591), Six Talent Peaks Project in Jiangsu Province (2014-YY-001), Jiangsu Provincial Medical Youth Talent (QNRC2016215), Suzhou Science and Education Youth Project (KJXW2016067), Suzhou Industrial Technology Innovation (SYSD2016046), National Key Research \& Development Plan of the Ministry of Science and Technology of the People's Republic of China (2018YFC1314900, 2018YFC1314901), the 2016 Industry Prospecting and Common Key Technology Key Projects of Jiangsu Province Science and Technology Department (BE2016002-4), the 2017 Projects of Jiangsu Provincial Department of Finance (2150510), and the 2016 Projects of Nanjing Science Bureau (201608003).

\section{Availability of data and materials}

Data are available upon reasonable request. The data used in the current study are available from the corresponding author on reasonable request.

\section{Declarations}

\section{Ethics approval and consent to participate}

This study was approved by the Institutional Animal Care and Use Committee of China Pharmaceutical University (IACUC-1910006).

\section{Consent for publication}

Not applicable.

\section{Competing interests}

The authors declare that they have no conflict of interest.

\section{Author details}

${ }^{1}$ Research Division of Clinical Pharmacology, The First Affiliated Hospital of Nanjing Medical University and Jiangsu Province Hospital, 300 Guangzhou 
Road, Nanjing 210009, China. ${ }^{2}$ Department of Pharmacy, Jiangsu Shengze Hospital, Nanjing Medical University, Suzhou, China. ${ }^{3}$ Department of Pharmacy, Nanjing Medical University, Nanjing, China. ${ }^{4}$ Department of Geriatrics Endocrinology, The First Affiliated Hospital of Nanjing Medical University, Jiangsu Province Hospital, 300 Guangzhou Road, Nanjing 210029, China.

Received: 29 September 2021 Accepted: 28 January 2022 Published online: 19 February 2022

\section{References}

Aydin C, Sarac B, Koyuncu A, Yildirim S, Sen M, Sarioglu Y. Relaxant effect of omeprazole and lansoprazole in guinea pig gallbladder muscle strips in vitro. J Gastroenterol. 2003;38(8):765-71. https://doi.org/10.1007/ s00535-003-1143-6.

Bano D, Ankarcrona M. Beyond the critical point: an overview of excitotoxicity, calcium overload and the downstream consequences. Neurosci Lett. 2018;663:79-85. https://doi.org/10.1016/j.neulet.2017.08.048.

Chen CH, Lin CL, Kao CH. Gastroesophageal reflux disease with proton pump inhibitor use is associated with an increased risk of osteoporosis: a nationwide population-based analysis. Osteoporos Int. 2016;27(6):2117-26. https://doi.org/10.1007/s00198-016-3510-1.

Chen J, Li L, Bai X, Xiao L, Shangguan J, Zhang W, et al. Inhibition of autophagy prevents panax notoginseng saponins (PNS) protection on cardiac myocytes against endoplasmic reticulum (ER) stress-induced mitochondrial injury, $\mathrm{Ca}\left({ }^{2+}\right)$ homeostasis and associated apoptosis. Front Pharmacol. 2021:12: 620812. https://doi.org/10.3389/fphar.2021.620812.

Chiu WT, Chang HA, Lin YH, Lin YS, Chang HT, Lin HH, et al. BCl(-)2 regulates store-operated $\mathrm{Ca}\left({ }^{2+}\right)$ entry to modulate ER stress-induced apoptosis. Cell Death Discov. 2018;4:37. https://doi.org/10.1038/s41420-018-0039-4.

Chou YF, Huang W, Dunn JC, Miller TA, Wu BM. The effect of biomimetic apatite structure on osteoblast viability, proliferation, and gene expression. Biomaterials. 2005;26(3):285-95. https://doi.org/10.1016/j.biomaterials. 2004.02.030.

Corley DA, Kubo A, Zhao W, Quesenberry C. Proton pump inhibitors and histamine-2 receptor antagonists are associated with hip fractures among at-risk patients. Gastroenterology. 2010;139(1):93-101. https://doi.org/10. 1053/j.gastro.2010.03.055.

Elias E, Targownik LE. The clinician's guide to proton pump inhibitor related adverse events. Drugs. 2019;79(7):715-31. https://doi.org/10.1007/ s40265-019-01110-3.

Filadi R, Pizzo P. ER-mitochondria tethering and $\mathrm{Ca}\left({ }^{2+)}\right.$ crosstalk: the IP3R team takes the field. Cell Calcium. 2019;84: 102101. https://doi.org/10.1016/j. ceca.2019.102101.

Fossmark R, Stunes AK, Petzold C, Waldum HL, Rubert M, Lian AM, et al. Decreased bone mineral density and reduced bone quality in $\mathrm{H}(+) / \mathrm{K}(+)$ ATPase beta-subunit deficient mice. J Cell Biochem. 2012;113(1):141-7. https://doi.org/10.1002/jcb.23337.

Grant K, Al-Adhami N, Tordoff J, Livesey J, Barbezat G, Reith D. Continuation of proton pump inhibitors from hospital to community. Pharm World Sci. 2006;28(4):189-93. https://doi.org/10.1007/s11096-006-9028-4.

Guo Y-S, Sun Z, Ma J, Cui W, Gao B, Zhang H-Y, et al. 17ß-Estradiol inhibits ER stress-induced apoptosis through promotion of TFII-I-dependent Grp78 induction in osteoblasts. Lab Invest. 2014;94(8):906-16. https://doi.org/ 10.1038/labinvest.2014.63.

Gyawali CP. Proton pump inhibitors in gastroesophageal reflux disease: friend or foe. Curr Gastroenterol Rep. 2017;19(9):46. https://doi.org/10.1007/ s11894-017-0586-5.

Han Y, You X, Xing W, Zhang Z, Zou W. Paracrine and endocrine actions of bone-the functions of secretory proteins from osteoblasts, osteocytes, and osteoclasts. Bone Res. 2018;6:16. https://doi.org/10.1038/ s41413-018-0019-6.

Histing T, Stenger D, Scheuer C, Metzger W, Garcia P, Holstein JH, et al. Pantoprazole, a proton pump inhibitor, delays fracture healing in mice. Calcif Tissue Int. 2012;90(6):507-14. https://doi.org/10.1007/s00223-012-9601-x.

Hoff M, Skovlund E, Skurtveit S, Meyer HE, Langhammer A, Sogaard AJ, et al. Proton pump inhibitors and fracture risk. The HUNT study Norway. Osteoporos Int. 2020;31(1):109-18. https://doi.org/10.1007/ s00198-019-05206-0.
Huang TC, Chiu PR, Chang WT, Hsieh BS, Huang YC, Cheng HL, et al. Epirubicin induces apoptosis in osteoblasts through death-receptor and mitochondrial pathways. Apoptosis. 2018;23(3-4):226-36. https://doi.org/10.1007/ s10495-018-1450-2.

Ito T, Jensen RT. Association of long-term proton pump inhibitor therapy with bone fractures and effects on absorption of calcium, vitamin B12, iron, and magnesium. Curr Gastroenterol Rep. 2010;12(6):448-57. https://doi. org/10.1007/s11894-010-0141-0.

Jo YPE, Ahn SB, Jo YK, Son B, Kim SH, Park YS, Kim HJ. A proton pump inhibitor's effect on bone metabolism mediated by osteoclast action in old age: a prospective randomized study. Gut Liver. 2015;9(5):607-14. https://doi. org/10.5009/gnl14135.

Jung $\mathrm{H}$, Best M, Akkus O. Microdamage induced calcium efflux from bone matrix activates intracellular calcium signaling in osteoblasts via L-type and T-type voltage-gated calcium channels. Bone. 2015;76:88-96. https:// doi.org/10.1016/j.bone.2015.03.014

Krebs J, Groenendyk J, Michalak M. Ca ${ }^{2+}$-signaling, alternative splicing and endoplasmic reticulum stress responses. Neurochem Res. 2011;36(7):1198-211. https://doi.org/10.1007/s11064-011-0431-4.

Li J, Yang S, Li X, Liu D, Wang Z, Guo J, et al. Role of endoplasmic reticulum stress in disuse osteoporosis. Bone. 2017;97:2-14. https://doi.org/10. 1016/j.bone.2016.12.009.

Li X, Meng L, Wang F, Hu X, Yu Y. Sodium fluoride induces apoptosis and autophagy via the endoplasmic reticulum stress pathway in MC3T3-E1 osteoblastic cells. Mol Cell Biochem. 2019;454(1-2):77-85. https://doi. org/10.1007/s11010-018-3454-1.

Liao L, Su X, Yang X, Hu C, Li B, Lv Y, et al. TNF-alpha inhibits FoxO1 by upregulating miR-705 to aggravate oxidative damage in bone marrowderived mesenchymal stem cells during osteoporosis. Stem Cells. 2016;34(4):1054-67. https://doi.org/10.1002/stem.2274.

Liu D, Genetos DC, Shao Y, Geist DJ, Li J, Ke HZ, et al. Activation of extracellularsignal regulated kinase (ERK1/2) by fluid shear is $\mathrm{Ca}\left({ }^{2+}\right)$ - and ATP-dependent in MC3T3-E1 osteoblasts. Bone. 2008:42(4):644-52. https://doi.org/10. 1016/j.bone.2007.09.058.

Liu H, Zhu R, Liu C, Ma R, Wang L, Chen B, et al. Evaluation of decalcification techniques for rat femurs using $\mathrm{HE}$ and immunohistochemical staining. Biomed Res Int. 2017;2017:9050754. https://doi.org/10.1155/2017/90507 54.

Luptak J, Kocmalova M, Franova S, Sutovsky J, Grendar M, Svihra J, et al. Involvement of calcium regulating ion channels in contractility of human isolated urinary bladder. Gen Physiol Biophys. 2018;37(4):391-8. https:// doi.org/10.4149/gpb 2017064.

Matuszewska A, Nowak B, Rzeszutko M, Zduniak K, Szandruk M, Jedrzejuk $D$, et al. Effects of long-term administration of pantoprazole on bone mineral density in young male rats. Pharmacol Rep. 2016;68(5):1060-4. https://doi.org/10.1016/j.pharep.2016.06.012.

Menger MM, Bremer P, Scheuer C, Rollmann MF, Braun BJ, Herath SC, et al. Pantoprazole impairs fracture healing in aged mice. Sci Rep. 2020;10(1):22376. https://doi.org/10.1038/s41598-020-79605-3.

Mohsin AA, Thompson J, Hu Y, Hollander J, Lesnefsky EJ, Chen Q. Endoplasmic reticulum stress-induced complex I defect: central role of calcium overload. Arch Biochem Biophys. 2020;683: 108299. https://doi.org/10.1016/j. abb.2020.108299

Nagaoka M, Maeda T, Chatani M, Handa K, Yamakawa T, Kiyohara S, et al. A delphinidin-enriched maqui berry extract improves bone metabolism and protects against bone loss in osteopenic mouse models. Antioxidants (basel). 2019;8(9):386. https://doi.org/10.3390/antiox8090386.

Nakamura S, Miki H, Kido S, Nakano A, Hiasa M, Oda A, et al. Activating transcription factor 4, an ER stress mediator, is required for, but excessive ER stress suppresses osteoblastogenesis by bortezomib. Int J Hematol. 2013;98(1):66-73. https://doi.org/10.1007/s12185-013-1367-z.

Naseri E, Yenisehirli A. Proton pump inhibitors omeprazole and lansoprazole induce relaxation of isolated human arteries. Eur J Pharmacol. 2006;531(1-3):226-31. https://doi.org/10.1016/j.ejphar.2005.12.025.

Nie Z, Deng S, Zhang L, Chen S, Lu Q, Peng H. Crocin protects against dexamethasoneinduced osteoblast apoptosis by inhibiting the ROS/ $\mathrm{Ca}^{2+}$ mediated mitochondrial pathway. Mol Med Rep. 2019;20(1):401-8. https://doi.org/10.3892/mmr.2019.10267. 
Olbe L, Carlsson E, Lindberg P. A proton-pump inhibitor expedition: the case histories of omeprazole and esomeprazole. Nat Rev Drug Discov. 2003;2(2):132-9. https://doi.org/10.1038/nrd1010.

Peterson JA, Crowther CM, Andrus MB, Kenealey JD. Resveratrol derivatives increase cytosolic calcium by inhibiting plasma membrane ATPase and inducing calcium release from the endoplasmic reticulum in prostate cancer cells. Biochem Biophys Rep. 2019;19: 100667. https://doi.org/10. 1016/j.bbrep.2019.100667.

Pihan P, Carreras-Sureda A, Hetz C. BCL-2 family: integrating stress responses at the ER to control cell demise. Cell Death Differ. 2017;24(9):1478-87. https://doi.org/10.1038/cdd.2017.82.

Poly TN, Islam MM, Yang HC, Wu CC, Li YC. Proton pump inhibitors and risk of hip fracture: a meta-analysis of observational studies. Osteoporos Int. 2018;30(1):103-14. https://doi.org/10.1007/s00198-018-4788-y.

Qiu S, Tao ZB, Tao L, Zhu Y. Melatonin induces mitochondrial apoptosis in osteoblasts by regulating the STIM1/cytosolic calcium elevation/ERK pathway. Life Sci. 2020;248: 117455. https://doi.org/10.1016/j.lfs.2020. 117455.

Sato AY, Tu X, McAndrews KA, Plotkin LI, Bellido T. Prevention of glucocorticoid induced-apoptosis of osteoblasts and osteocytes by protecting against endoplasmic reticulum (ER) stress in vitro and in vivo in female mice. Bone. 2015;73:60-8. https://doi.org/10.1016/j.bone.2014.12.012.

Sato Y, Ishihara N, Nagayama D, Saiki A, Tatsuno I. 7-ketocholesterol induces apoptosis of MC3T3-E1 cells associated with reactive oxygen species generation, endoplasmic reticulum stress and caspase-3/7 dependent pathway. Mol Genet Metab Rep. 2017;10:56-60. https://doi.org/10.1016/j. ymgmr.2017.01.006.

Schillinger W, Teucher N, Sossalla S, Kettlewell S, Werner C, Raddatz D, et al. Negative inotropy of the gastric proton pump inhibitor pantoprazole in myocardium from humans and rabbits: evaluation of mechanisms. Circulation. 2007;116(1):57-66. https://doi.org/10.1161/CIRCULATIO NAHA.106.666008.

Sosnoski DM, Gay CV. NCX3 is a major functional isoform of the sodiumcalcium exchanger in osteoblasts. J Cell Biochem. 2008;103(4):1101-10. https://doi.org/10.1002/jcb.21483.

Sun LN, Cao Y, Li YQ, Fang YQ, Zhang HW, Wang MF, et al. Impact of Gastric $\mathrm{H}^{+}$/ $\mathrm{K}^{+}$-ATPase rs 2733743 on the intragastric $\mathrm{pH}$-values of dexlansoprazole injection in Chinese subjects. Front Pharmacol. 2017;8:670. https://doi. org/10.3389/fphar.2017.00670.

Tantikanlayaporn D, Wichit P, Suksen K, Suksamrarn A, Piyachaturawat P. Andrographolide modulates OPG/RANKL axis to promote osteoblastic differentiation in MC3T3-E1 cells and protects bone loss during estrogen deficiency in rats. Biomed Pharmacother. 2020;131: 110763. https://doi. org/10.1016/j.biopha.2020.110763.

Toyoshima C, Cornelius F. New crystal structures of Pll-type ATPases: excitement continues. Curr Opin Struct Biol. 2013;23(4):507-14. https://doi.org/ 10.1016/j.sbi.2013.06.005.

van der Hoorn MMC, Tett SE, de Vries OJ, Dobson AJ, Peeters G. The effect of dose and type of proton pump inhibitor use on risk of fractures and osteoporosis treatment in older Australian women: a prospective cohort study. Bone. 2015;81:675-82. https://doi.org/10.1016/j.bone.2015.08.024.

Wang J, Zhao Y, Cheng X, Li Y, Xu H, Manthari RK, et al. Effects of different $\mathrm{Ca}\left({ }^{2+}\right)$ level on fluoride-induced apoptosis pathway of endoplasmic reticulum in the rabbit osteoblast in vitro. Food Chem Toxicol. 2018;116(Pt B):189-95. https://doi.org/10.1016/j.fct.2018.04.013.

Wang J, Yang J, Cheng X, Xiao R, Zhao Y, Xu H, et al. Calcium alleviates fluorideinduced bone damage by inhibiting endoplasmic reticulum stress and mitochondrial dysfunction. J Agric Food Chem. 2019;67(39):10832-43. https://doi.org/10.1021/acs.jafc.9b04295.

Wu J, Kaufman RJ. From acute ER stress to physiological roles of the unfolded protein response. Cell Death Differ. 2006;13(3):374-84. https://doi.org/10. 1038/sj.cdd.4401840.

Wu Y, Yang M, Fan J, Peng Y, Deng L, Ding Y, et al. Deficiency of osteoblastic Arl6ip5 impaired osteoblast differentiation and enhanced osteoclastogenesis via disturbance of ER calcium homeostasis and induction of ER stress-mediated apoptosis. Cell Death Dis. 2014;5: e1464. https://doi.org/ 10.1038/cddis.2014.427.

Wu L, Zhang G, Guo C, Pan Y. Intracellular $\mathrm{Ca}\left({ }^{2+}\right)$ signaling mediates IGF1-induced osteogenic differentiation in bone marrow mesenchymal stem cells. Biochem Biophys Res Commun. 2020;527(1):200-6. https:// doi.org/10.1016/j.bbrc.2020.04.048.
Yenisehirli A, Onur R. Specific H+/K(+)-ATPase inhibitors decreased contractile responses of isolated rat vas deferens. Pharmacol Res. 2006;54(6):397405. https://doi.org/10.1016/j.phrs.2006.07.005.

Yin X, Zhou C, Li J, Liu R, Shi B, Yuan Q, et al. Autophagy in bone homeostasis and the onset of osteoporosis. Bone Res. 2019;7(1). https://doi.org/10. 1038/s41413-019-0058-7.

Yu EW, Bauer SR, Bain PA, Bauer DC. Proton pump inhibitors and risk of fractures: a meta-analysis of 11 international studies. Am J Med. 2011;124(6):519-26. https://doi.org/10.1016/j.amjmed.2011.01.007.

Yu L, Wang X, Gao X, Tong J, Zhang J. The calcium transient characteristics induced by fluid shear stress affect the osteoblast proliferation. Exp Cell Res. 2018;362(1):51-62. https://doi.org/10.1016/j.yexcr.2017.11.001.

Yuan FL, Li X, Lu WG, Li CW, Li JP, Wang Y. The vacuolar ATPase in bone cells: a potential therapeutic target in osteoporosis. Mol Biol Rep. 2010;37(7):3561-6. https://doi.org/10.1007/s11033-010-0004-7.

Yurtsever AS, Pektas M, Ozkur M, Un I, Erenmemisoglu A, Buyukafsar K. Proton pump inhibitors omeprazole, lansoprazole and pantoprazole induce relaxation in the rat lower oesophageal sphincter. J Pharm Pharmacol. 2011;63(10):1295-300. https://doi.org/10.1111/j.2042-7158.2011.01333.x.

Zhang JK, Yang L, Meng GL, Yuan Z, Fan J, Li D, et al. Protection by salidroside against bone loss via inhibition of oxidative stress and bone-resorbing mediators. PLoS ONE. 2013;8(2): e57251. https://doi.org/10.1371/journal. pone.0057251.

Zhang IX, Ren J, Vadrevu S, Raghavan M, Satin LS. ER stress increases storeoperated $\mathrm{Ca}^{2+}$ ) entry (SOCE) and augments basal insulin secretion in pancreatic beta cells. J Biol Chem. 2020;295(17):5685-700. https://doi. org/10.1074/jbc.RA120.012721.

Zhu SY, Zhuang JS, Wu Q, Liu ZY, Liao CR, Luo SG, et al. Advanced oxidation protein products induce pre-osteoblast apoptosis through a nicotinamide adenine dinucleotide phosphate oxidase-dependent, mitogenactivated protein kinases-mediated intrinsic apoptosis pathway. Aging Cell. 2018;17(4): e12764. https://doi.org/10.1111/acel.12764.

\section{Publisher's Note}

Springer Nature remains neutral with regard to jurisdictional claims in published maps and institutional affiliations.

Ready to submit your research? Choose BMC and benefit from

- fast, convenient online submission

- thorough peer review by experienced researchers in your field

- rapid publication on acceptance

- support for research data, including large and complex data types

- gold Open Access which fosters wider collaboration and increased citations

- maximum visibility for your research: over $100 \mathrm{M}$ website views per year

At BMC, research is always in progress.

Learn more biomedcentral.com/submissions 